\title{
DISTRIBUTION OF BALSAMORHIZA ROSEA IN RATTLESNAKE HILLS WITH RESPECT TO VARIOUS ENVIRONMENTAL FACTORS
}

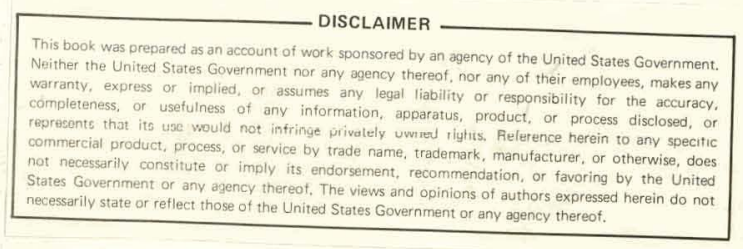

By

MARY ANN PARKHURST

A thesis submitted in partial fulfillment of the requirements for the degree of

MASTERS OF SCIENCE

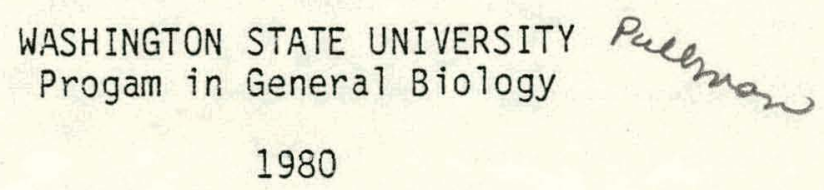




\section{DISCLAIMER}

This report was prepared as an account of work sponsored by an agency of the United States Government. Neither the United States Government nor any agency Thereof, nor any of their employees, makes any warranty, express or implied, or assumes any legal liability or responsibility for the accuracy, completeness, or usefulness of any information, apparatus, product, or process disclosed, or represents that its use would not infringe privately owned rights. Reference herein to any specific commercial product, process, or service by trade name, trademark, manufacturer, or otherwise does not necessarily constitute or imply its endorsement, recommendation, or favoring by the United States Government or any agency thereof. The views and opinions of authors expressed herein do not necessarily state or reflect those of the United States Government or any agency thereof. 


\section{DISCLAIMER}

Portions of this document may be illegible in electronic image products. Images are produced from the best available original document. 
To the Faculty of Washington State University:

The members of the Committee appointed to examine the thes is of MARY ANN PARKHURST find it satisfactory and recommend that it be accepted. 


\section{ACKNOWLEDGMENT}

This work was supported in part by the U.S. Department of Energy under Contract DE-ACO6-76RLO 1830.

Pacific Northwest Laboratory Operated by Battelle

Richland, Washington 99352 


\section{DISTRIBUTION OF BALSAMORHIZA ROSEA IN RATTLESNAKE HILLS WITH RESPECT TO VARIOUS ENVIRONMENTAL FACTORS}

\section{ABSTRACT}

by Mary Ann Parkhurst, M.S.

Washington State University, 1980

Chairman: Ronald H. Sauer

Balsamorhiza rosea (Compositae), a suffrutescent perennial, is found on several rocky hilltops with sparse canopy cover in Eastern Washington. This study investigated $\underline{B}$. rosea's abundance and its associated species along several physical gradients. Important elements of microclimate selected for this analysis were elevation, slope aspect, slope angle, and soil depth. Results show that the occurrence of $\underline{B}$. rosea is associated more strongly with soil depth than with other factors examined. The distribution of B. rosea was not fully explained by the factors in this study. Other potential factors determining its distribution are discussed. 
TABLE OF CONTENTS

Page

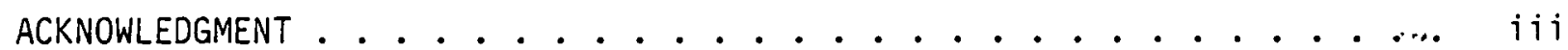

ABSTRACT .......................... .... iv

LIST OF TABLES . . . . . . . . . . . . . . . . . . . . . . vi

LIST OF ILLUSTRATIONS . . . . . . . . . . . . . . . . . . vii

Chapter

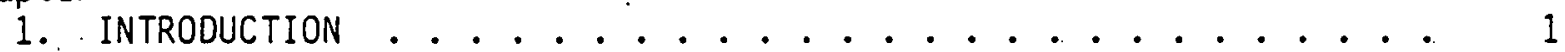

2. METHODS ........................ 4

3. RESULTS . . . . . . . . . . . . . . . . . . . . . . . 9 9

4. DISCUSSION .................................... 37

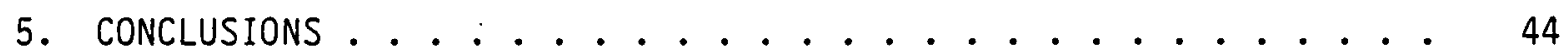

LITERATURE CITED . . . . . . . . . . . . . . . . . . 4 46 
1. Transect data .. . . . . . . . . . . . . 10

2. Linear correlation coefficients of physical parameters with abundance of Balsamorhiza rosea .............. 15

3. Canopy cover of vegetation within transects . . . . . . . 18

4. Frequency of vegetation within transects . . . . . . . . . . 22

5. Comparison of three plant categories . . . . . . . . . 32

6. Linear correlation coefficients of biotic factors and rock cover with abundance of Balsamorhiza rosea. . . . . . . . 35

7. Seedlings from artificial planting . . . . . . . . . . 36

8. Seed viability . . . . . . . . . . . . . . . . . 36 
1. Elevation versus Balsamorhiza rosea cover . . . . . . . . 12

2. Slope aspect versus Balsamorhiza rosea cover . . . . . . . . 13

3. Slope angle versus Balsamorhiza rosea cover. . . . . . . . . . 14

4. Soil depth versus Balsamorhiza rosea cover . . . . . . . . . 16

5. Agropyron spicatum cover versus Balsamorhiza rosea cover . . . . . 26

6. Poa sandbergii cover versus Balsamorhiza rosea cover . . . . . . . 27

7. Total plant cover versus Balsamorhiza rosea cover . . . . . . 28

8. Rock cover versus Balsamorhiza rosea cover . . . . . . . . . 29

9. Richness index of species diversity versus Balsamorhiza rosea cover . . . . . . . . . . . . . 30

10. Simpson's index of diversity versus Balsamorhiza rosea cover . ... 31

11. Balsamorhiza rosea frequency versus B. rosea cover . . . . . . . 34 
CHAPTER 1

INTRODUCTION

Balsamorhiza rosea (Compositae) is a plant listed in the Federal Register as threatened on the proposed threatened and endangered species list (Department of the Interior, 1975). Its known distribution lies solely within the State of Washington where it is found on several isolated hills. Its limited distribution prompted this investigation into various environmental factors to see how they influence $\underline{B}$. rosea's range of habitat. Observation of its nonuniform distribution on stony ridges during a preliminary visit to Rattlesnake Hills, Benton County, Washington suggested several physical factors for study: elevation, slope angle, slope aspect, rock cover, and soil depth. These are some of the major factors influencing microclimate. Additionally, plant species in the communities in which $B$. rosea exists and communities adjacent to its habitat were viewed as candidates for investigation.

Balsamorhiza rosea is a member of the Heliantheae tribe of the Compositae family. It is a perennial with bright yellow flowers that bloom in early spring and turn rosey brown with age. Its leaves are crenate to pinnatifid. The flower stems and leaves grow in a lateral manner hugging the ground surface. As they age and start to dry the stems become erect prior to losing their blooms. The plant, a suffrutescent, is dormant by the beginning of summer.

The root of this plant is a carrot-like tap root which becomes firmly established in the soil. While there is no specific evidence to support 
B. rosea's reproduction in this manner, this is one of several Balsamorhiza species which may produce new plants from deep-seated, slender, short creeping roots (Hitchcock, 1973). Both ray flowers and disk flowers are fertile and have a haploid chromosome number of nineteen (Weber, 1946).

B. rosea is localized in Washington east of the Cascade Mountains. Weber (1946) collected specimens for chromosomal study at the summits of hills southwest of Touchet, Washington in Walla Walla County. Hitchcock et al. (1955-1969) described B. rosea's distribution at three south-central Washington localities indicating the type locality as Rattlesnake Hills. St. John (1956) described its occurrence in Spokane County as local. It has been obșerved mainiy on ridge crests in several Benton County hills. Rickard et al. (1978) found $B_{\text {. rosea }}$ on Rattlesnake Hills, Jump-Off-Joe Butte, Horse Heaven Hills, Badger Mountain, and Red Mountain, all in Benton County.

Rattlesnake Hills are located within longitudes $119^{\circ}$. and $121^{\circ}$, and within $46^{\circ}$ and $47^{\circ} \mathrm{N}$ latitude. This basalt formation rises to slightly above $3400 \mathrm{ft}(1036 \mathrm{~m})$ for about $3.1 \mathrm{mi}(5 \mathrm{~km})$. The southwest side of these hills has a gentle slope which supports dryland wheat farming. The northeast slope drops steeply with about a $25^{\circ}$ slope to $2130 \mathrm{ft}(650 \mathrm{~m})$, then eases gently to the Cold Creek Valley elevation of $490 \mathrm{ft}(150 \mathrm{~m})$ extending into the Columbia Basin (Thorp and Hinds, 1977 ).

Climatology of the area as identified by three weather stations at the crest of Rattlesnake Hills shows the total October to May rainfall average as $6.5 \mathrm{in.}(16.6 \mathrm{~cm})$ and the total January to December average rainfall as $7.5 \mathrm{in}$. $(19.2 \mathrm{~cm})$ during 1968-1975. Average minimum and maximum temperatures for the same period reached $-17.3^{\circ} \mathrm{C}$ to $7.2^{\circ} \mathrm{C}$ in January, the coldest month, and $3.8^{\circ} \mathrm{C}$ to $36.5^{\circ} \mathrm{C}$ in July, the warmest month (Thorp and Hinds, 1977). Prevailing winds on the crest are strong and nearly constant, frequently faster than in the surrounding grasslands at lower elevations. 
Vegetation on the sumit appears stunted, probably as a result of the heavy winds and thin, rocky soils. Most of the plants growing on top are cushion plants or other piants with a short habit. Poa sandbergii (Sandberg's bluegrass) and Agropyron spicatum (bluebunch wheatgrass) are the main grasses inhabiting the area. 


\section{CHAPTER 2}

\section{METHODS}

The sampling strategy was a systematic approach based initially on the elevation gradient. The intent was to characterize each study area by the parameters under investigation and to explain Balsamorhiza rosea's abundance as a function of the various environmental factors. No attempt was made to map the distribution of B. rosea.

Sampling was concentrated along the Rattlesnake Ridge within the range of elevations of $B$. rosea's known existence. Searching below its lowest known elevation yielded additional sites. Attempts were made to sample B. rosea on all four slope aspects at elevations where it was located. A variety of slope angles were scouted with the intention of noting its "preferred" angle as a function of its abundance.

The physical parameters were measured at each of 41 sites in which data were recorded. Elevation was measured using an altimeter, slope aspect determinations were made using a simple magnetic compass, and slope angle was measured with a Brunton compass. Soil depth was sampled at meter intervals along the 20-m cover transect using an edaphic penetrometer (a sharp metal rod) which was forced through the soil until it met a rock surface that prevented penetration.

Canopy cover transects (Daubenmire, 1959) were taken at 1-m intervals along a 20-m transect. The starting point was randomized as much as possible by placing it, after walking a random number of steps, forward and to the side 
of each community sampled. A stake was pounded into the ground at this starting point. A meter tape was stretched $20 \mathrm{~m}$ out from the starting point, perpendicular to the slope contours. The vertical projection of the canopy of each species was estimated as a percentage of the area it covered with the $20 \times 50-\mathrm{cm}$ quadrat. To reduce estimating error the canopy was estimated to be in one of seven classes (Daubenmire, 1959):

$\begin{array}{ccc}\frac{\% \text { Cover }}{0} & \begin{array}{c}\text { Number } \\ \text { Designation }\end{array} \\ >0 \text { to } 5 & 0 \\ >5 \text { to } 25 & 2 \\ >25 \text { to } 50 & 3 \\ >50 \text { to } 75 & 4 \\ >75 \text { to } 95 & 5 \\ >95 \text { to } 100 & 6\end{array}$

The $0.1 \mathrm{~m}^{2}$ rectangular quadrat was used for the estimation of all plant species in the plot. Absence of flowers or other diagnostic material made some plants impossible to identify. These were recorded as unknowns. An estimate of surface rock cover was handled in the same way as canopy cover. Twenty quadrats were sampled in each transect rather than the customary 50 quadrats because the frequent species, those that would have the most influence on B. rosea, were adequately sampled with 20 quadrats.

Cover data were recorded on computer data sheets, punched on cards, and analyzed by COVER, a fortran program code (Sauer and Owzarski, 1979). For each transect the total percentage cover was calculated and for each species, the 
mean percentage cover, the sum of $x$, sum of $x^{2}$, standard deviation; coefficient of variation, standard error, and $95 \%$ confidence limits around the percentage cover were computed.

Three estimates of species diversity (richness, Simpson's Index, and Shannon Weaver Index) were computed by COVER using the transects for the general equation $\mathrm{N}_{\mathrm{a}}=\left(\mathrm{p}_{1}^{a}+\mathrm{p}_{2}^{a}+\mathrm{p}_{3}{ }^{a}+\ldots \mathrm{p}_{i}{ }^{a}\right)^{1 / 1-a}$ where $\mathrm{a}$ is the numerical index and $p_{j}$ is the proportion of the ith species. The richness measure of diversity $(a=0)$ qives all species sampled an equal emphasis which actually emphasizes the rare species. Simpson's Index $(a=2)$ reverses this by emphasizing the common species with less emphasis on the rare. Modification of the traditional Simpson's Index allows it to be numerically compared to richness (Hill, 1973). The Shannon-Weaver Index $(a=1)$ is a compromise of the other two.

Correlations of $B$. rosea with the other factors were studied with the UCLA BMDP-77 Biomedical Computer Programs (Brown, 1977). The data input for each transect included elevation, slope angle, and slope aspect as coded by a system dividing the compass into four units using the following code:

\begin{tabular}{|c|c|c|c|}
\hline & Slope & & $\begin{array}{c}\text { Numerical } \\
\text { Designation } \\
\end{array}$ \\
\hline zero & slope & & 0. \\
\hline 315 & -45 & $(N)$ & 1 \\
\hline 45 & -135 & $(E)$ & 2 \\
\hline 135 & -225 & $(S)$ & 3 \\
\hline 225 & -315 & $(W)$ & 4 \\
\hline
\end{tabular}

Other measurements included were rock cover, soil depth, B. rosea cover, B. rosea frequency (measured as the percentage of quadrats in the transect in 
which B. rosea was present), Agropyron spicatum cover, Poa sandbergi $\underline{\text { s cover, }}$ total plant cover and species diversity in terms of richness and Simpson's Index. A. spicatum and $\underline{P}$. sandbergii were chosen because of their apparent negative correlations with $B$. rosea's abundance.

These correlation values were calculated and the points plotted using BMDP-77 program \#6D entitled "Bivariate (Scatter) Plots." Cluster analysis and multiple regression programs were also used in the search for relationships in the data.

In addition to cover studies on existing plants, I decided to test the hypotheses that B. rosea can grow at lower elevations and that its growth is particularly restricted by competition, especially with A. spicatum. I collected seeds from B. rosea in early summer and froze them in a conventional freezer for more than two months for stratification. The seeds were randomly separated into groups of ten. This same procedure was applied to B. careyana, which is known to inhabit lower elevations, frequently lives in A. spicatum communities, and sometimes coexists with B. rosea.

I chose two adjacent sites at $1200 \mathrm{ft}(365 \mathrm{~m})$ and two adjacent sites at $2700 \mathrm{ft}(823 \mathrm{~m})$ for this experiment. Each site consisted of a $5-\mathrm{m}$ distance between two metal posts. One plot at each elevation was a partially rocky area with little vegetation. The other was a sandy area with small to moderate amounts of $A$. spicatum. A $20 \times 50-\mathrm{cm}$ rectangle strung in two rows over the width and five rows over the length provided equidistant spacing for planting ten seeds per quadrat. On March 1, 1979 ten $B$. rosea seeds were planted at one meter intervals within the $5-\mathrm{m}$ experimental plots. B. careyana seeds were planted at one meter intervals starting at the half-meter. Seeds were planted by making a hole about $1 \mathrm{~cm}$ deep at the junction of the strings on the 
rectangle, placing the seed into the hole and covering it with as little disturbance to the soil as possible. Some variation of the intended point of planting was required to miss rocks and other plants.

Seeds were collected again in early summer and a second planting on

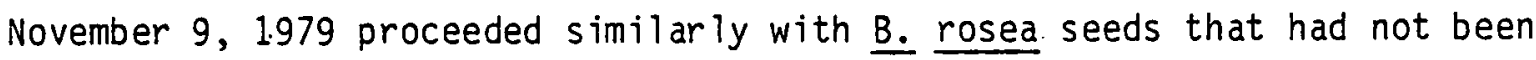
stratified. The seeds were planted at each $1 / 2-m$ on the line between the two boundary posts at each of the four plots.

Laboratory germination studies were conducted on the stratified seeds at several different incubation temperatures to see effects of temperature on germination. Ten seeds each of $\underline{B}$. rosea and $\underline{B}$. careyana were placed in petri dishes on wet filter paper in dark incubators at temperatores of $60^{\circ}, 70^{\circ}$, and $80^{\circ} \mathrm{F}\left(15.6^{\circ}, 21.1^{\circ}\right.$, and $\left.26.7^{\circ} \mathrm{C}\right)$.

Several treatments were tried on a second and third set of seeds to help initiate germination. Both sets were sterilized in a $5 \% \mathrm{v} / \mathrm{v}$ chlorox solution. One set was thoroughly rinsed with distilled water and placed in the incubators. The other set soaked in distilled water overnight before placement into the dishes in the incubators.

To help interpret the results of the germination tests I ran a seed

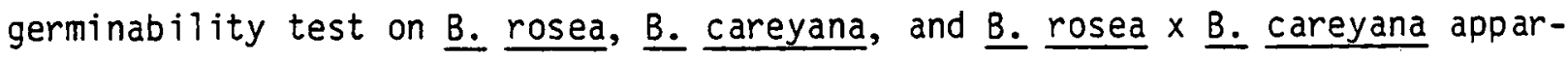
ent hybrids to learn the variability of the mature-looking ray and disk seeds. The few remaining seeds at this point limited the scale of this determination. The seeds were tested in accordance with a laboratory manual (Machlis and Torrey, 1973). Each seed was cut in half lengthwise through the embryo. The halves were immersed in a $0.1 \% \mathrm{wt} / \mathrm{v}$ solution of tetrazolium chloride. The seeds were placed in the dark and were examined at intervals of $1 / 2 \mathrm{hr}, 1 \mathrm{hr}$, 1-1/2 hr, $2 \mathrm{hr}, 4 \mathrm{hr}$, and $20 \mathrm{hr}$. Those seeds exhibiting the carmine red stain indicative of respiration were recorded as viable. 
CHAPTER 3

\section{RESULTS}

The physical parameters at each transect location (elevation, slope aspect, slope angle, and average soil depth) are listed in Table 1. Canopy coverage of Balsamorhiza rosea, Agropyron spicatum, Poa sandbergii, total plant cover, and rock cover are listed in the table as average percentages over the transect. The frequency of $\underline{B}$. rosea and species diversity as measured by richness, the Shannon-Weaver Index, and Simpson's Index are also included in the table.

The relationship between $B$. rosea cover and elevation is illustrated in Figure 1. The sampling yielded a range of elevations from $648 \mathrm{ft}(198 \mathrm{~m})$ to $3583 \mathrm{ft}(1093 \mathrm{~m})$ at which B. rosea was found on Rattlesnake Hills. The upper limits of the distribution as a function of elevation are represented by a broken line. The cover percentages are the averages of the canopy cover in the twenty quadrats per transect.

The relationship between $\underline{B}$. rosea cover and slope aspect (the magnetic compass direction of a given slope) is shown in the graph in Figure 2. Slope aspect has been abbreviated using the numbers $1,2,3$, and 4 to represent the directions north, east, south, and west, respectively.

Slope angle was the next parameter evaluated and, as the data show, B. rosea was present on slopes up to $23.5^{\circ}$. Figure 3 is a graph of slope angle versus $\underline{B}$. rosea cover. The dotted line shows the upper boundary of this relationship. 


\begin{tabular}{|c|c|c|c|c|c|}
\hline Transect & $\begin{array}{l}\text { Elevation } \\
(\mathrm{ft})\end{array}$ & $\begin{array}{l}\text { Slope Aspect } \\
\text { (compass degrees) }\end{array}$ & Slope Angle & $\begin{array}{l}\text { Soil Depth } \\
\text { (cm) }\end{array}$ & $\begin{array}{l}\text { Rock Cover } \\
(\%)\end{array}$ \\
\hline $\begin{array}{l}1 \\
2 \\
3 \\
4 \\
5\end{array}$ & $\begin{array}{l}3455 \\
3460 \\
2275 \\
2275 \\
2510\end{array}$ & $\begin{array}{r}180 \\
270 \\
178 \\
92 \\
226\end{array}$ & $\begin{array}{r}7.0 \\
0 \\
9.0 \\
11.5 \\
7.5\end{array}$ & $\begin{array}{r}8.3 \\
12.2 \\
7.7 \\
13.8 \\
14.8\end{array}$ & $\begin{array}{l}96 \\
96 \\
52 \\
61 \\
94\end{array}$ \\
\hline $\begin{array}{r}6 \\
7 \\
8 \\
9 \\
10\end{array}$ & $\begin{array}{l}2525 \\
2530 \\
3440 \\
3430 \\
3420\end{array}$ & $\begin{array}{r}44 \\
134 \\
262 \\
170 \\
20\end{array}$ & $\begin{array}{r}23.5 \\
7.0 \\
6.0 \\
9.5 \\
8.5\end{array}$ & $\begin{array}{l}15.5 \\
13.3 \\
16.5 \\
10.5 \\
12.8\end{array}$ & $\begin{array}{l}77 \\
91 \\
84 \\
90 \\
66\end{array}$ \\
\hline $\begin{array}{l}11 \\
12 \\
13 \\
14 \\
15 .\end{array}$ & $\begin{array}{l}3420 \\
3160 \\
3440 \\
2960 \\
2940\end{array}$ & $\begin{array}{r}270 \\
100 \\
107 \\
282 \\
88\end{array}$ & $\begin{array}{r}7.5 \\
16.5 \\
7.0 \\
5.0 \\
8.0\end{array}$ & $\begin{array}{r}24.8 \\
15.5 \\
12.0 \\
8.2 \\
9.2\end{array}$ & $\begin{array}{l}87 \\
75 \\
77 \\
90 \\
93\end{array}$ \\
\hline $\begin{array}{l}16 \\
17 \\
18 \\
19 \\
20\end{array}$ & $\begin{array}{l}2930 \\
2960 \\
3175 \\
3160 \\
3020\end{array}$ & $\begin{array}{r}2 \\
212 \\
256 \\
184 \\
34\end{array}$ & $\begin{array}{r}11.5 \\
10.5 \\
9.0 \\
5.5 \\
7.0\end{array}$ & $\begin{array}{r}7.0 \\
8.2 \\
7.6 \\
5.8 \\
10.0\end{array}$ & $\begin{array}{l}87 \\
95 \\
78 \\
84 \\
85\end{array}$ \\
\hline $\begin{array}{l}21 \\
22 \\
23 \\
24 \\
25\end{array}$ & $\begin{array}{l}2735 \\
2725 \\
2760 \\
2785 \\
2560\end{array}$ & $\begin{array}{r}210 \\
108 \\
36 \\
240 \\
316\end{array}$ & $\begin{array}{r}6.5 \\
6.0 \\
13.0 \\
7.0 \\
3.5\end{array}$ & $\begin{array}{c}11.8 \\
9.5 \\
-- \\
9.6 \\
7.8\end{array}$ & $\begin{array}{l}85 \\
91 \\
88 \\
86 \\
86\end{array}$ \\
\hline $\begin{array}{l}26 \\
27 \\
28 \\
29 \\
30\end{array}$ & $\begin{array}{l}2555 \\
3400 \\
3000 \\
2415 \\
2435\end{array}$ & $\begin{array}{l}254 \\
248 \\
252 \\
332 \\
264\end{array}$ & $\begin{array}{c}7.0 \\
3.5 \\
0 \\
13.0 \\
10.0\end{array}$ & $\begin{array}{r}\ddot{8.0} \\
12.3 \\
21.5 \\
21.5\end{array}$ & $\begin{array}{l}80 \\
98 \\
78 \\
43 \\
87\end{array}$ \\
\hline $\begin{array}{l}31 \\
32 \\
33 \\
34 \\
35\end{array}$ & $\begin{array}{l}3450 \\
3400 \\
1610 \\
1900 \\
2160\end{array}$ & $\begin{array}{r}160 \\
200 \\
8 \\
22 \\
40\end{array}$ & $\begin{array}{r}4.0 \\
15.0 \\
8.0 \\
19.0 \\
13.0\end{array}$ & $\begin{array}{r}21.8 \\
18.5 \\
>80.0 \\
>80.0 \\
>80.0\end{array}$ & $\begin{array}{r}34 \\
7 ? \\
0 \\
0 \\
0\end{array}$ \\
\hline $\begin{array}{l}36 \\
37 \\
38 \\
39 \\
40 \\
41\end{array}$ & $\begin{array}{l}2180 \\
2550 \\
2750 \\
3080 \\
3360 \\
1200\end{array}$ & $\begin{array}{r}106 \\
172 \\
140 \\
180 \\
150 \\
40\end{array}$ & $\begin{array}{c}4.0 \\
11.0 \\
12.0 \\
0 \\
13.0 \\
0\end{array}$ & $\begin{array}{r}12.0 \\
7.5 \\
15.0 \\
22.0 \\
39.3 \\
>80.0\end{array}$ & $\begin{array}{r}45 \\
73 \\
45 \\
29 \\
1 \\
0\end{array}$ \\
\hline
\end{tabular}


TABLE 1.--(Cont inued)

\begin{tabular}{|c|c|c|c|c|c|c|}
\hline \multicolumn{2}{|c|}{ Balsamorhiza rosea } & \multirow[b]{2}{*}{$\begin{array}{l}\text { Total Canopy } \\
\text { \% Cover }\end{array}$} & \multirow[b]{2}{*}{$\frac{\text { Agropyron }}{\% \text { covicatum }}$} & \multirow[b]{2}{*}{$\frac{\text { Poa sandbergii }}{\% \text { Cover }}$} & \multicolumn{2}{|c|}{ Diversity } \\
\hline$\%$ Cover & $\%$ Frequency & & & & Richness & $\begin{array}{l}\text { Simpson's } \\
\text { Index }\end{array}$ \\
\hline $\begin{array}{l}2.0 \\
9.5 \\
1.6 \\
0 \\
5.3\end{array}$ & $\begin{array}{r}30 \\
45 \\
15 \\
0 \\
60\end{array}$ & $\begin{array}{l}52 \\
53 \\
58 \\
53 \\
39\end{array}$ & $\begin{array}{r}0.0 \\
1.1 \\
6.1 \\
11.6 \\
3.8\end{array}$ & $\begin{array}{l}18.0 \\
10.3 \\
34.9 \\
19.3 \\
12.9\end{array}$ & $\begin{array}{l}13 \\
14 \\
12 \\
12 \\
15\end{array}$ & $\begin{array}{l}5.2 \\
6.4 \\
2.6 \\
4.3 \\
5.3\end{array}$ \\
\hline $\begin{array}{r}1.1 \\
10.1 \\
2.5 \\
1.1 \\
6.4\end{array}$ & $\begin{array}{l}20 \\
50 \\
25 \\
20 \\
60\end{array}$ & $\begin{array}{l}39 \\
57 \\
30 \\
38 \\
40\end{array}$ & $\begin{array}{r}6.0 \\
12.1 \\
5.9 \\
9.4 \\
9.1\end{array}$ & $\begin{array}{r}19.9 \\
17.5 \\
8.6 \\
17.0 \\
12.1\end{array}$ & $\begin{array}{r}12 \\
9 \\
12 \\
13 \\
13\end{array}$ & $\begin{array}{l}3.2 \\
4.7 \\
5.4 \\
3.6 \\
5.2\end{array}$ \\
\hline $\begin{array}{l}8.8 \\
7.0 \\
3.3 \\
9.1 \\
6.1\end{array}$ & $\begin{array}{l}60 \\
60 \\
30 \\
75 \\
50\end{array}$ & $\begin{array}{l}35 \\
56 \\
38 \\
34 \\
37\end{array}$ & $\begin{array}{l}3.8 \\
6.9 \\
5.8 \\
5.3 \\
8.4\end{array}$ & $\begin{array}{r}12.4 \\
14.9 \\
18.1 \\
2.8 \\
7.5\end{array}$ & $\begin{array}{r}16 \\
13 \\
8 \\
9 \\
11\end{array}$ & $\begin{array}{l}4.5 \\
6.6 \\
3.6 \\
3.8 \\
5.4\end{array}$ \\
\hline $\begin{array}{r}4.6 \\
4.0 \\
7.6 \\
8.1 \\
13.5\end{array}$ & $\begin{array}{l}40 \\
60 \\
40 \\
60 \\
85\end{array}$ & $\begin{array}{l}35 \\
29 \\
32 \\
30 \\
51\end{array}$ & $\begin{array}{l}9.6 \\
5.4 \\
1.4 \\
6.1 \\
2.6\end{array}$ & $\begin{array}{r}6.0 \\
11.3 \\
13.5 \\
8.8 \\
13.6\end{array}$ & $\begin{array}{r}11 \\
11 \\
11 \\
9 \\
14\end{array}$ & $\begin{array}{l}5.1 \\
4.1 \\
3.8 \\
4.5 \\
5.1\end{array}$ \\
\hline $\begin{array}{l}3.6 \\
2.1 \\
2.1 \\
3.5 \\
8.8\end{array}$ & $\begin{array}{l}70 \\
15 \\
15 \\
40 \\
80\end{array}$ & $\begin{array}{l}28 \\
24 \\
26 \\
28 \\
30\end{array}$ & $\begin{array}{r}11.5 \\
1.9 \\
4.4 \\
2.0 \\
4.8\end{array}$ & $\begin{array}{r}3.0 \\
10.4 \\
7.5 \\
6.1 \\
8.6\end{array}$ & $\begin{array}{r}13 \\
9 \\
15 \\
10 \\
9\end{array}$ & $\begin{array}{l}4.4 \\
3.9 \\
6.5 \\
3.8 \\
4.5\end{array}$ \\
\hline $\begin{array}{r}10.1 \\
5.8 \\
16.9 \\
4.0 \\
4.5\end{array}$ & $\begin{array}{l}65 \\
40 \\
60 \\
20 \\
35\end{array}$ & $\begin{array}{l}41 \\
36 \\
43 \\
27 \\
36\end{array}$ & $\begin{array}{r}3.8 \\
2.4 \\
4.3 \\
12.0 \\
2.8\end{array}$ & $\begin{array}{r}12.9 \\
7.5 \\
3.1 \\
5.6 \\
14.1\end{array}$ & $\begin{array}{l}10 \\
12 \\
11 \\
11 \\
14\end{array}$ & $\begin{array}{l}4.7 \\
6.0 \\
4.7 \\
3.6 \\
4.4\end{array}$ \\
\hline $\begin{array}{l}1.3 \\
3.4 \\
0 \\
0 \\
0\end{array}$ & $\begin{array}{r}25 \\
60 \\
0 \\
0 \\
0\end{array}$ & $\begin{array}{r}51 \\
47 \\
109 \\
107 \\
87\end{array}$ & $\begin{array}{r}12.6 \\
5.0 \\
27.6 \\
39.0 \\
36.9\end{array}$ & $\begin{array}{r}9.5 \\
14.4 \\
33.8 \\
36.8 \\
26.8\end{array}$ & $\begin{array}{r}12 \\
13 \\
8 \\
14 \\
14\end{array}$ & $\begin{array}{l}4.6 \\
2.5 \\
3.9 \\
3.7 \\
3.3\end{array}$ \\
\hline $\begin{array}{l}3.9 \\
0.7 \\
5.1 \\
0.1 \\
0 \\
0\end{array}$ & $\begin{array}{r}35 \\
5 \\
15 \\
5 \\
0 \\
0\end{array}$ & $\begin{array}{l}46 \\
27 \\
45 \\
85 \\
79 \\
73\end{array}$ & $\begin{array}{r}5.6 \\
11.1 \\
6.3 \\
12.5 \\
20.1 \\
1.6\end{array}$ & $\begin{array}{r}28.9 \\
7.9 \\
25.8 \\
33.5 \\
13.3 \\
34.4\end{array}$ & $\begin{array}{r}9 \\
11 \\
9 \\
15 \\
18 \\
12\end{array}$ & $\begin{array}{l}2.8 \\
3.7 \\
2.7 \\
4.9 \\
5.1 \\
2.7\end{array}$ \\
\hline
\end{tabular}




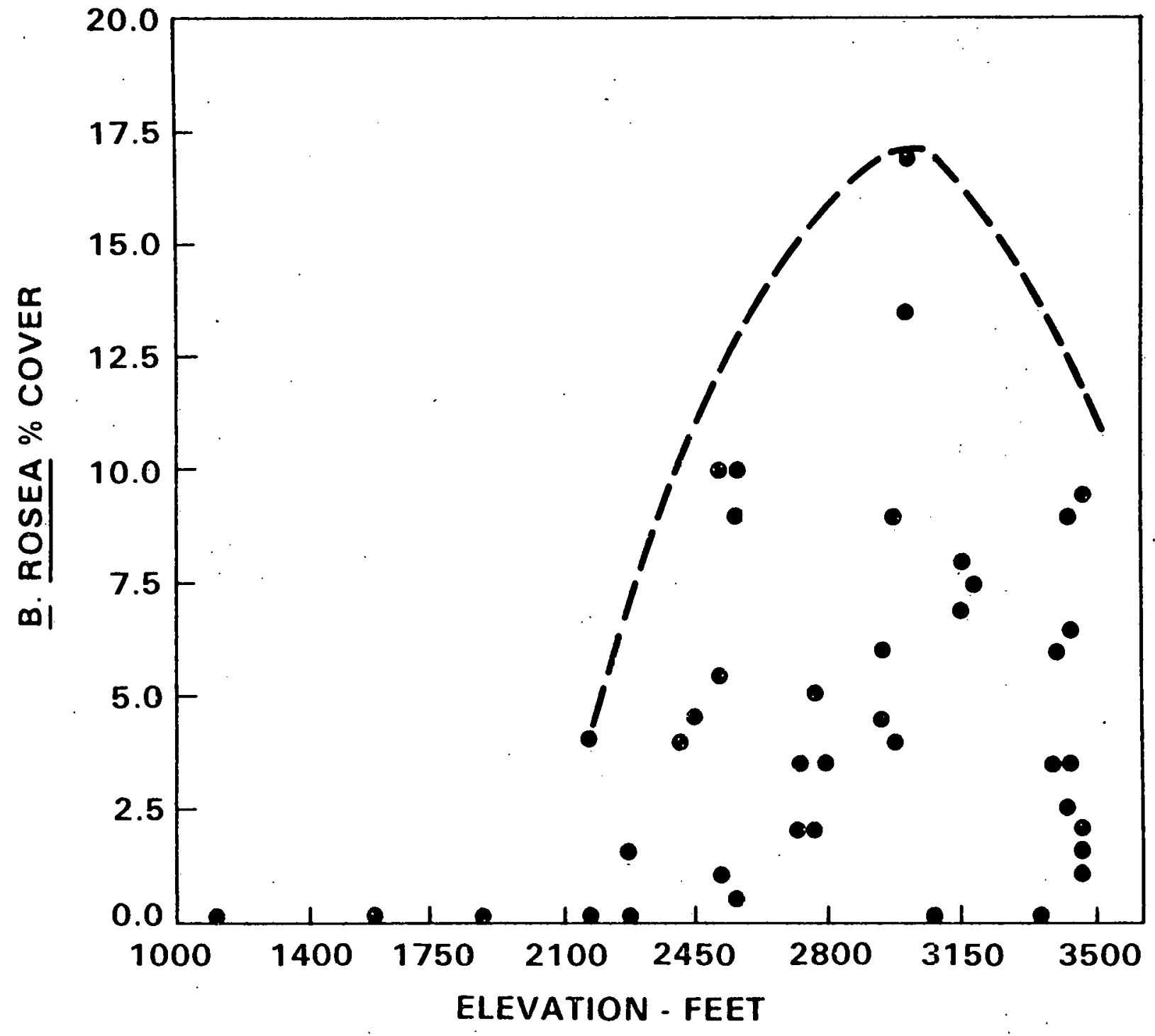

Fig. 1.--Elevation versus Balsamorhiza rosea coven 


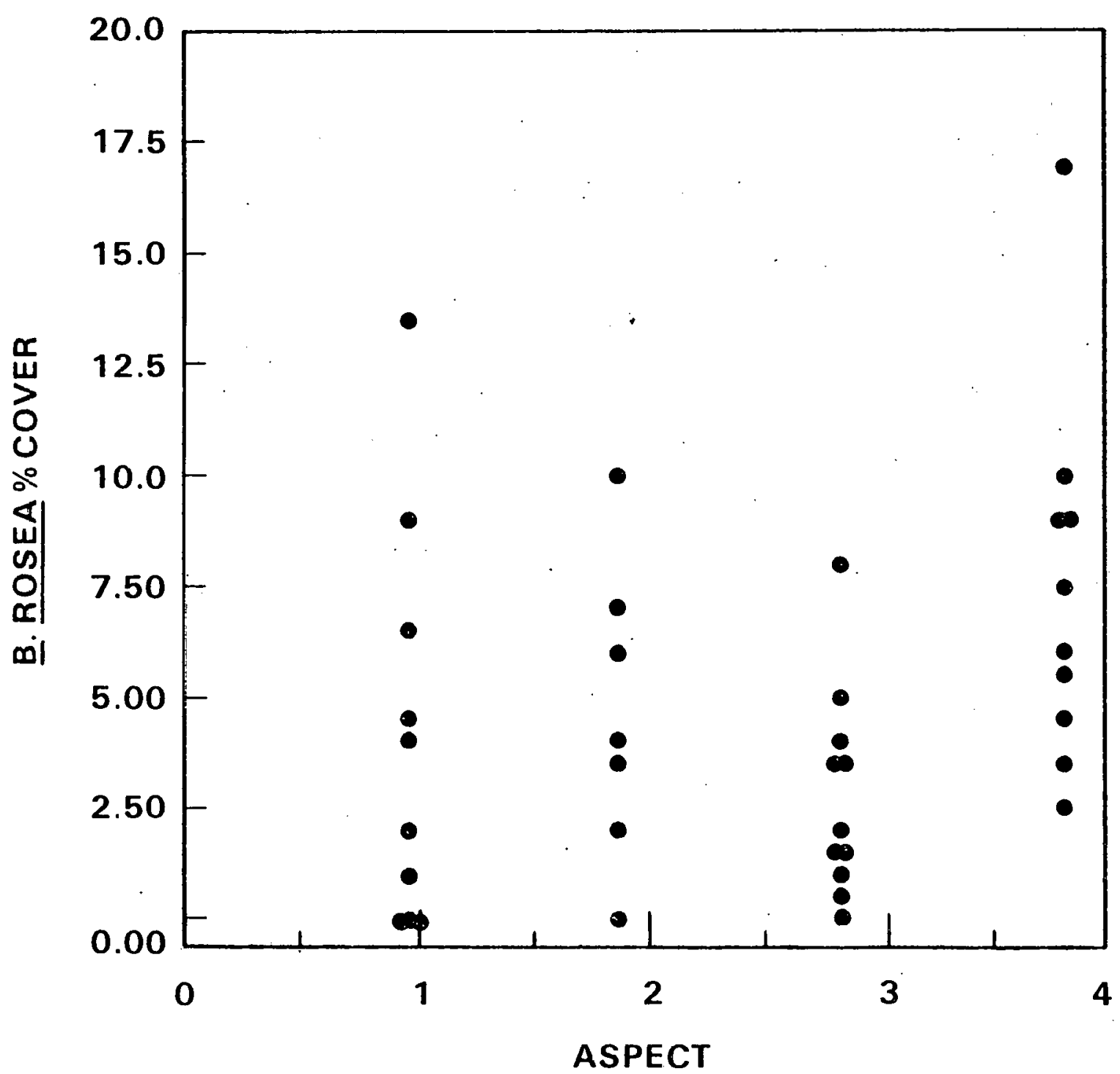

Fig. 2.--Slope aspect versus Balsamorhiza rosea cover 


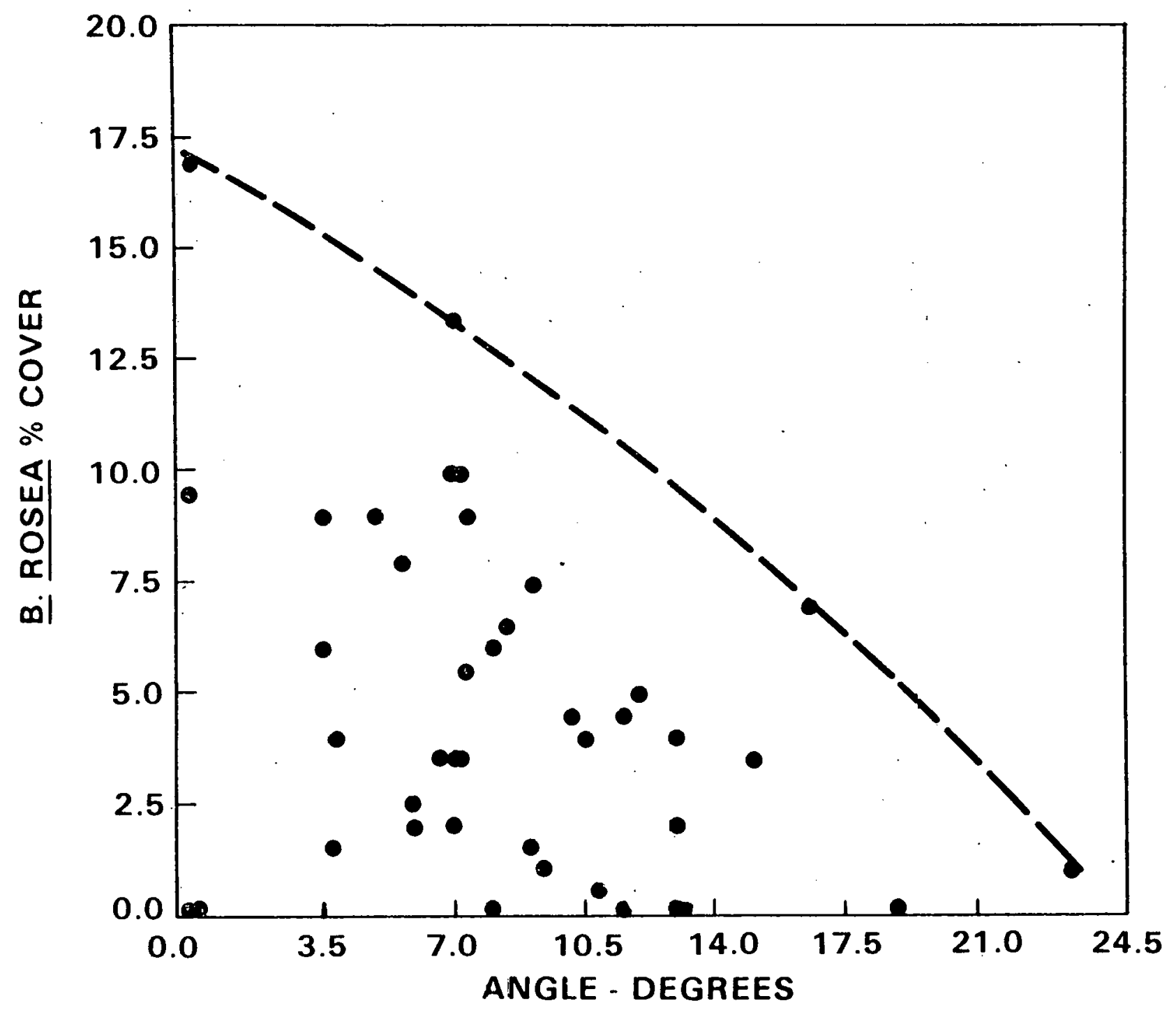

Fig. 3.--Slope angle versus Balsamorhiza rosea cower 
Soil depth in centimeters is plotted in Figure 4 in relation to $\underline{B}$. rosea cover. Soil depth data are the means of soil depth taken at $1-m$ intervals along the $20 \mathrm{~m}$ transects. B. rosea grew in soils varying in depths less than $2.4 \mathrm{in.}$ to $8.7 \mathrm{in.}(6 \mathrm{~cm}$ to $22 \mathrm{~cm})$. The mean depth of the transects containing some $B$. rosea was $12.7 \mathrm{~cm}$ with a standard deviation of $5.2 \mathrm{~cm}$. The transects wịthout B. rosea had a mean depth of $>62 \mathrm{~cm}$ and a standard deviation of 28.8 assuming for this calculation that $>80 \mathrm{~cm}$ equaled $80 \mathrm{~cm}$. Transects 23 and 26 were not relocated during the soil depth sampling as the stakes marking the transects had apparently been removed.

Linear correlation analysis were run with the bivariate plots. Two data sets on the results are indicated in Table 2. The first set is based on all 41 transects. The second is the same analysis excluding those transects with no B. rosea.

TABLE 2.--Linear correlation coefficients of physical parameters with abundance of Balsamorhiza rosea

\begin{tabular}{lll}
\hline & All 41 Transects & B. rosea transects \\
\cline { 2 - 4 } Factor & $\%$ Cover Frequency & $\%$ Cover Frequency \\
\hline
\end{tabular}

B. rosea versus:

$\begin{array}{lcccc}\text { Elevation } & .301 & .393^{\mathrm{a}} & .051 & .106 \\ \text { Aspect } & .244 & .306 & .107 & .149 \\ \text { Angle } & -.359^{\mathrm{a}} & -.246 & -.347^{\mathrm{a}} & -.185 \\ \text { Soil depth } & -.439^{b} & -.548^{b} & -.144 & -.188\end{array}$

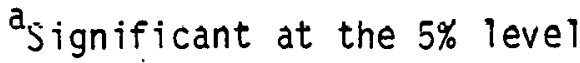

$\mathrm{b}_{\text {Significant at the } 0.1 \% \text { level }}$
}

Significance testing of the correlation coefficients indicates that the coefficient for soil depth versus $\underline{B}$. rosea's abundance is significantly 


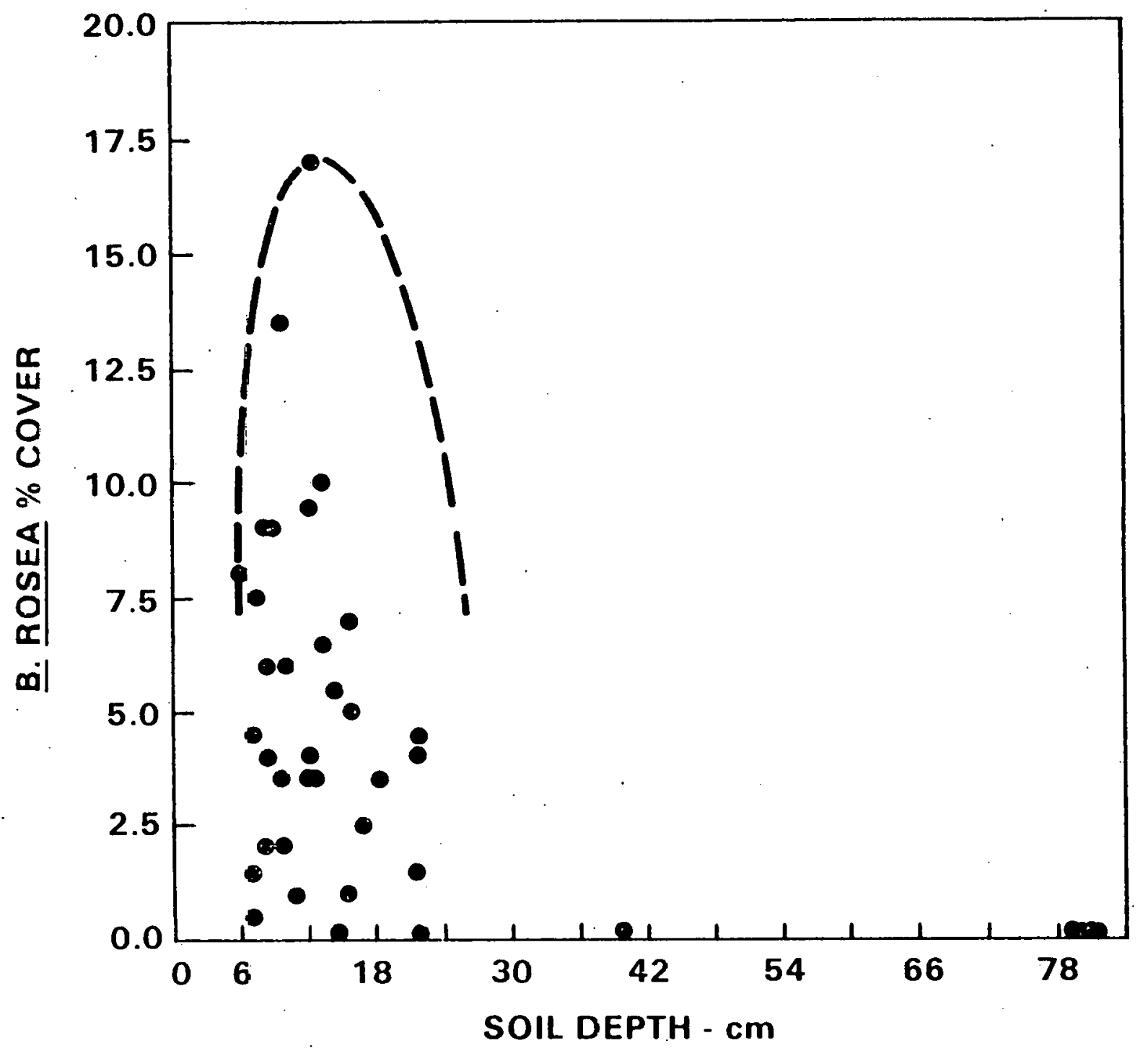

Fig. 4.--Soil depth versus Balsamorhiza rosea cover 
different than zero. This suggests that these factors are linearly related. The negative sign identifies this as an inverse relationship. Cluster analysis and multiple regression programs did not provide any useful information in data interpretation.

The cover sampling yielded the species listed in Table 3. These have been separated into three classes: a no $\underline{B}$. rosea category, a low $\underline{B}$. rosea density category with cover from $>0$ to $5 \%$, and a high density of $\underline{B}$. rosea cover where the canopy exceeded $5 \%$. Six of the 41 transects had no B. rosea canopy cover. There were 19 transects in the low density group and 16 in the high density group. The results in the table are expressed as the average percentage of canopy cover for each species within each category. These numbers are calculated for each species as the total percentage of canopy cover in all transects in the category divided by the number of transects in that category.

The following species were represented by an average of at least $1 \%$ canopy cover in the first category (no B. rosea):

Achillea millefolium

Agropyron spicatum

Artemisia tridentata

Bromus tectorum

Crepis atrabarba

Erigeron filifolius

Eriogonum sphaerocephalum

Poa cusickii

Poa sandbergii 
TABLE 3.--Canopy cover of vegetation within transects

\begin{tabular}{|c|c|c|c|}
\hline Species & No $\frac{B .}{\text { Cover }}$ & $\begin{array}{l}\frac{\text { B. }}{\text { Cover }} \\
>0-5 \%\end{array}$ & $\begin{array}{c}\text { B. } \begin{array}{c}\text { rosea } \\
\text { Cover } \\
>5 \%\end{array} \\
\end{array}$ \\
\hline Achillea millefolium & 1.27 & 0.23 & 0.07 \\
\hline Agropyron spicatum & 24.13 & 6.43 & 5.14 \\
\hline Antennaria dimorpha & 0.17 & 0.56 & - \\
\hline Arabis cusickii & - & 0.09 & 0.21 \\
\hline Arenaria franklinii & - & 0.13 & 0.12 \\
\hline Artemisia tridentata & $\quad 15.20$ & 0.20 & 0.55 \\
\hline Aster canescens & - & 0.01 & - \\
\hline Astragalus purshii & - & 0.06 & 0.12 \\
\hline Astragalus sclerocarpus & - & 0.05 & - \\
\hline Balsamorhiza careyana & 0.18 & 0.09 & - \\
\hline Brodiaea douglasii & 0.02 & & \\
\hline Bromus tectorum & 4.67 & 0.86 & 0.98 \\
\hline Castilleja lutescens & - & - & - \\
\hline Chenopodium sp. & - & - & - \\
\hline Collinsia sparsiflora & 0.03 & 0.03 & 0.05 \\
\hline Crepis atrabarba & 1.62 & - & - \\
\hline Crepis occidentalis & - & 0.29 & 0.38 \\
\hline Cryptantha pterocarya & - & 0.01 & 0.01 \\
\hline Cymopterus tercbinthimus & - & 0.01 & 0.01 \\
\hline Descurania pinnata & 0.08 & 0.12 & 0.06 \\
\hline Erigeron filifolius & 1.47 & - & - \\
\hline Erigeron linearis & 0.15 & .19 & .01 \\
\hline Erigeron poliospermus & - & 0.18 & 0.49 \\
\hline
\end{tabular}


TABLE 3.--(Continued)

\begin{tabular}{|c|c|c|c|}
\hline Species & No $\frac{B}{\text { Cover }}$ & $\begin{array}{l}\text { B. } \frac{\text { rosea }}{\text { Cover }} \\
>0-5 \%\end{array}$ & $\begin{array}{l}\text { B. } \frac{\text { rosea }}{\text { cover }} \\
25 \%\end{array}$ \\
\hline Eriogonum sphaerocephalum & 1.40 & .55 & 1.07 \\
\hline Eriogonum thymoides & 0.25 & 0.95 & 0.62 \\
\hline Galium multiflorum & - & - & 0.01 \\
\hline Haplopappus stenophy 1.lus & 0.32 & 2.14 & 1.59 \\
\hline Hordum sp. & - & 0.01 & - \\
\hline Lithospermum ruderale & 0.15 & - & - \\
\hline Lomatium macrocarpus & 0.10 & 0.44 & 0.29 \\
\hline Lomatium triternatum & 0.08 & - & - \\
\hline Lupinus laxiflorus & 0.23 & 0.29 & - \\
\hline Lupinus sp. & 0.15 & 0.15 & 0.98 \\
\hline \multicolumn{4}{|l|}{ Lupinus sulphureus } \\
\hline Microser is sp. & - & - & 0.09 \\
\hline Microsteris gracilis & 0.90 & - & - \\
\hline Penstemon gairdner $\mathrm{i}$ & - & 0.05 & 0.10 \\
\hline Phace lia hastata & - & - & 0.06 \\
\hline Phace lia linear is & 0.37 & 0.01 & - \\
\hline Phlox hoodii & - & 3.93 & 3.31 \\
\hline Phiox longifolia & 0.07 & 0.85 & 3.04 \\
\hline Phoenicaulis cherianthoides & - & 0.04 & - \\
\hline Plantago patagonica & 0.78 & 0.03 & - \\
\hline Plectritis macrocera & 0.10 & - & - \\
\hline Poa cusickij & 1.85 & - & 0.09 \\
\hline Poa sandbergii & 24.40 & 13.35 & 11.51 \\
\hline Salsola kali & 0.03 & - & - \\
\hline
\end{tabular}


TABLE 3.--(Continued)

\begin{tabular}{lccc}
\multicolumn{1}{c}{ Species } & No B. rosea & $\begin{array}{c}\text { B. } \frac{\text { rosea }}{\text { Cover }} \\
>0-5 \%\end{array}$ & $\begin{array}{c}\text { B. } \frac{\text { rosea }}{\text { Cover }} \\
\lambda 5 \%\end{array}$ \\
\hline Sisymbrium altissimum & 0.03 & 0.03 & 0.02 \\
Sitanion hystrix & - & 0.14 & - \\
Stipa thurberiana & - & 0.09 & - \\
\hline Zigadenus sp. & 0.17 & 0.01 & - \\
\hline
\end{tabular}


The low $\underline{B}$. rosea cover category had these species present in canopy covers exceeding $1 \%$ :

\author{
Agropyron spicatum \\ Eriogonum sphaerocephalum \\ Haplopappus stenophyllus \\ Phlox hoodii \\ Poa sandberqii
}

The high $\underline{B}$. rosea cover category shows the same species list of canopy cover exceeding $1 \%$ with the addition of Phlox longifolia.

The frequency sumary in Table 4 lists the species and the percentage of time the species was present in the 20 quadrats of each transect for each category. For example, the frequency of Achillea millefolium is recorded as $10 \%$ in the no $B$. rosea class. This means that within the 6 transects in this class, 12 of the 120 sample quadrats contained at least one Achillea millefolium plant.

The most frequent species in the first class using an arbitrary $10 \%$ cover percentage cutoff are these:

Achillea millefolium

Agropyron spicatum

Bromus ter tonrum

Crepis atrabarba

Erigeron filifolius

Microsteris gracilis 
TABLE 4.--Frequency of vegetation within transects

\begin{tabular}{|c|c|c|c|}
\hline Species & No $\frac{B}{\text { Cover }}$ & $\begin{array}{l}\frac{\text { B. }}{\text { Co }} \frac{\text { rosea }}{\text { ver }} \\
>0-5 \%\end{array}$ & $\begin{array}{c}\text { B. } \begin{array}{c}\text { rosea } \\
\text { Cover } \\
>5 \%\end{array} \\
\end{array}$ \\
\hline Achiliea millefolium & 10 & 2.6 & 1.1 \\
\hline Agropyron spicatum & 68 & 53 & 45 \\
\hline Antennaria dimorpha & 6.7 & 4.5 & - \\
\hline Arabis cusickii & - & 0.8 & 2.7 \\
\hline Arenaria franklinii & - & 2.6 & 1.9 \\
\hline Artemisia tridentata & 47 & 0.5 & 0.9 \\
\hline Aster canescens & - & 0.3 & - \\
\hline Astragalus leibergii & - & $0.8^{\circ}$ & - \\
\hline Astragalus purshii & - & 2.4 & 3.8 \\
\hline Astragalus sclerocarpus & - & 0.5 & 0.6 \\
\hline Balsamorhiza careyana & 3.3 & 1.1 & - \\
\hline Balsamorhiza rosea & - & 30.3 & 56.6 \\
\hline Brodiaea douglasii & 0.8 & - & - \\
\hline Bromus tectorum & 38 & 22 & 24 \\
\hline Castilleja lutescens & - & & 0.9 \\
\hline Chenopodium sp. & - & 0.3 & 2.5 \\
\hline Collinsia sparsiflora & - & 1.3 & 0.9 \\
\hline Crepis atrabarba & 24 & - & - \\
\hline Crepis occidentalis & - & 4.2 & 5.3 \\
\hline Cryptantha pterocarya & - & 0.3 & 0.3 \\
\hline Cymopterus terebinthimus & - & 1.1 & - \\
\hline Descurania pinnata & 3.3 & 3.7 & 2.5 \\
\hline Epilobium paniculatum & 4.2 & - & - \\
\hline Erigeron filifolius & 10 & - & - \\
\hline
\end{tabular}


TABLE 4.--(Continued)

\begin{tabular}{|c|c|c|c|}
\hline Species & No $\frac{\text { B. }}{\text { Cóver }} \frac{\text { rosea }}{2}$ & $\begin{array}{l}\text { B. rosea } \\
\text { Cover } \\
>0-5 \%\end{array}$ & $\begin{array}{c}\text { B. } \frac{\text { rosea }}{\text { Cover }} \\
.>5 \%\end{array}$ \\
\hline Erigeron linearis & 1.7 & 2.9 & - \\
\hline Erigeron poliospermus & - & 1.1 & 3.8 \\
\hline Eriogonum sphaerocephalum & 5.8 & 15 & 9.7 \\
\hline Eriogonum thymoides & 1.7 & 7.4 & 4.7 \\
\hline Galium multiflorum & - & - & 0.6 \\
\hline Haplopappus stenophyllus & 0.8 & 22 & 17 \\
\hline Hordum sp. & - & 0.5 & - \\
\hline Lithospermum ruderale & 1.7 & - & - \\
\hline Lomatium macrocarpus & 4.2 & 9.7 & 7.8 \\
\hline Lomatium triternatum & 3.3 & - & - \\
\hline Lupinus laxiflorus & 5.0 & 4.2 & - \\
\hline Lupinus sp. & 0.8 & 0.8 & 4.7 \\
\hline Lupinus sulphureus & 0.8 & 0.3 & - \\
\hline Microseris sp. & - & - & 0.6 \\
\hline Microster is gracilis & 15 & - & - \\
\hline Penstemon gairdner $\mathrm{i}$ & - & 0.8 & 0.9 \\
\hline Phace lia hastata & - & - & 0.6 \\
\hline Phacelia linearis & 2.5 & 1.1 & 1.3 \\
\hline Phlox hoodii. & - & 42 & 52 \\
\hline Phlox longifolia & 14 & 2.1 & - \\
\hline Phoenicaulis cherianthoides & - & 0.3 & -- \\
\hline Plantago patagonica & - & 1.1 & - \\
\hline Plectrit is macrocera & 4.2 & - & - \\
\hline Poa cusickii & 13 & - & - \\
\hline Poa sandbergii & 88 & 92 & 91 \\
\hline
\end{tabular}


TABLE 4.---(Continued)

\begin{tabular}{|c|c|c|c|c|}
\hline Species & 1 & No $\frac{B}{\text { Cover }} \frac{\text { rosea }}{}$ & $\begin{array}{l}\text { B. } \frac{\text { rosea }}{\text { Cover }} \\
>0-5 \%\end{array}$ & $\begin{array}{c}\text { B. } \begin{array}{c}\text { rosea } \\
>5 \%\end{array} \\
\text { over }\end{array}$ \\
\hline Salsola kali & & 1.7 & - & - \\
\hline Sisymbrium altissimum & & 1.7 & 1.3 & 0.9 \\
\hline Sitanion hystrix & & - & 0.5 & 0.5 \\
\hline Stipa thurberiana & · & - & 1.1 & - \\
\hline Zigadenus sp. & & 6.7 & 0.3 & - \\
\hline
\end{tabular}


Phlox longifolia

Poa cusickij

Poa sandbergii

The most frequent species in the second category were:

Agropyron spicatum

Balsamorhiza rosea

Bromus tectorum

Eriogonum sphaerocephalum

Haplopappus stenophyllus

Phlox hoodii

Poa sandbergii

The third class frequency list is almost identical to the second, except that it excludes Eriogonum sphaerocephalum, which had a frequency slightly less than $10 \%$.

Relationships between the abundance of $\underline{B}$. rosea and the plant community composition were evaluated with bivariate plots of total plant cover or individual species cover versus $\underline{B}$. rosea. All species with frequency percentages in excess of $9 \%$ were initally considered for this analysis. Visual inspection of plots, except those of Agropyron spicatum and poa sandbergii, showed no strong correlations. Bivariate plotting using the BMDP-6D program graphically displayed the data and statistcally analyzed it for linear correlations with these variables: Agropyron spicatum cover, Poa sandbergii cover, total plant cover, rock cover, richness of plant diversity, and Simpson's diversity index. These graphs are shown in Figures 5 through 10. 


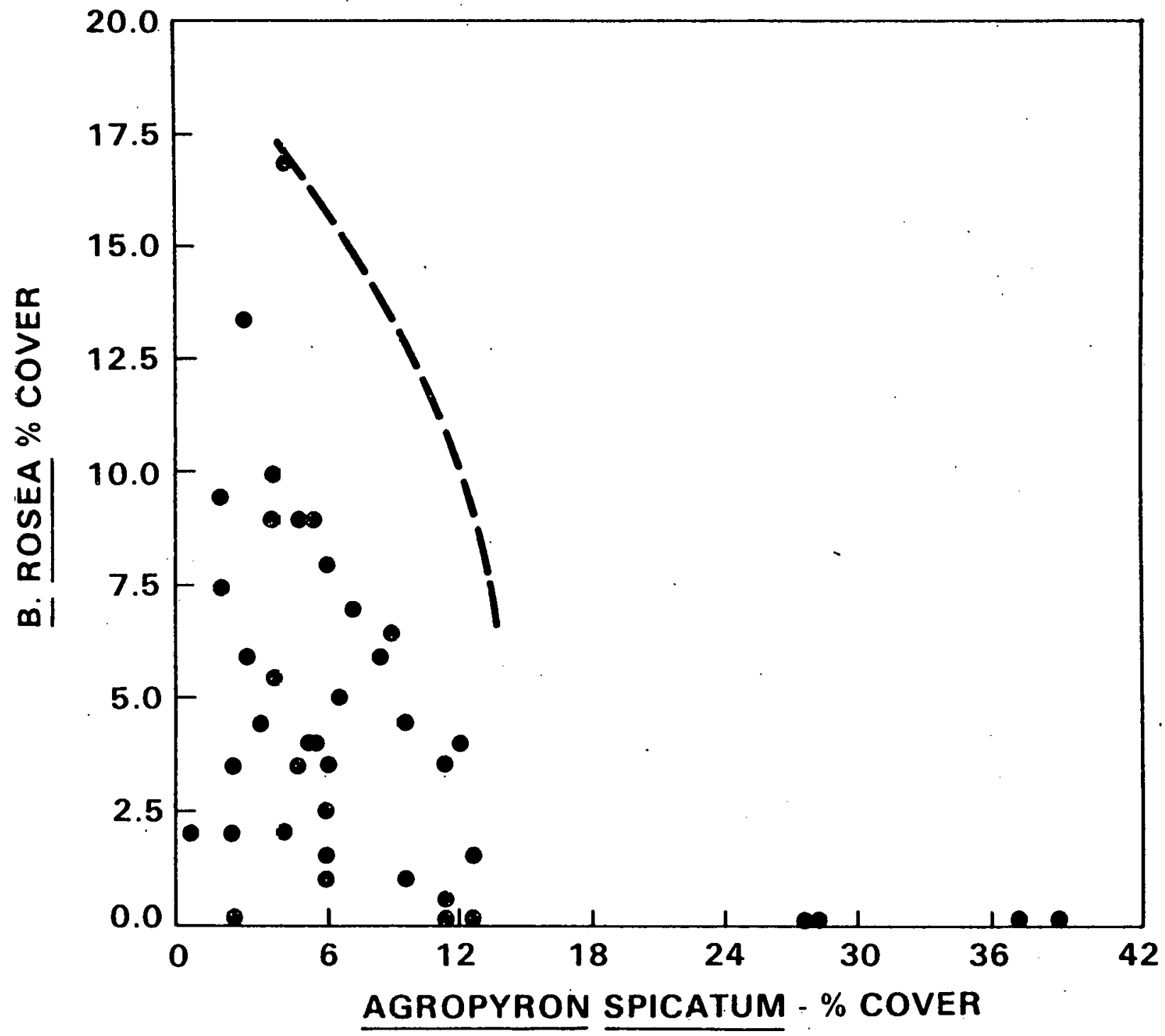

Fig. 5.--Agropyron spicatum cover versus Balsamorhiza rosea cover 


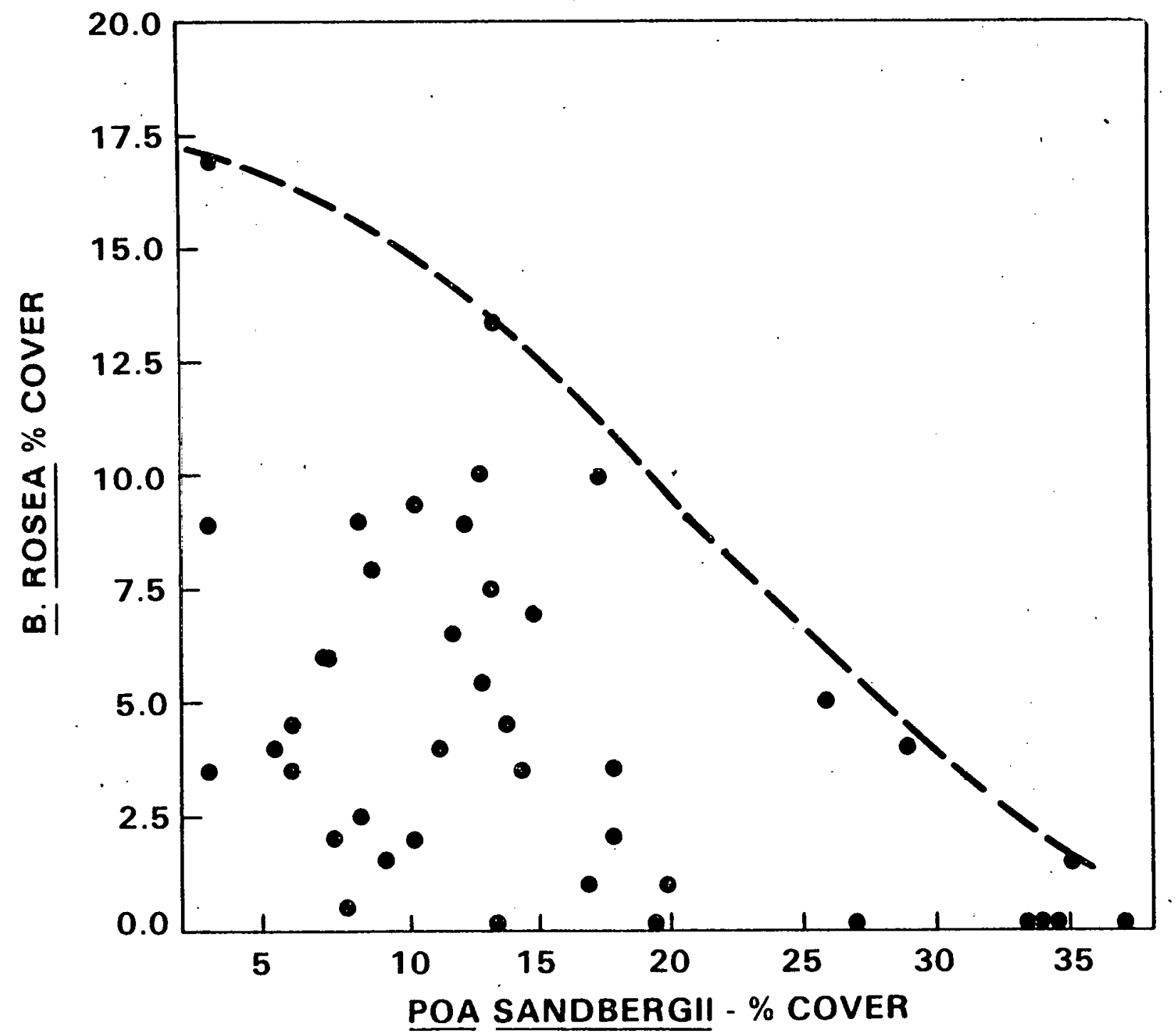

Fig. 6.--Poa sandbergii cover versus Balsamorhiza rosea cover 


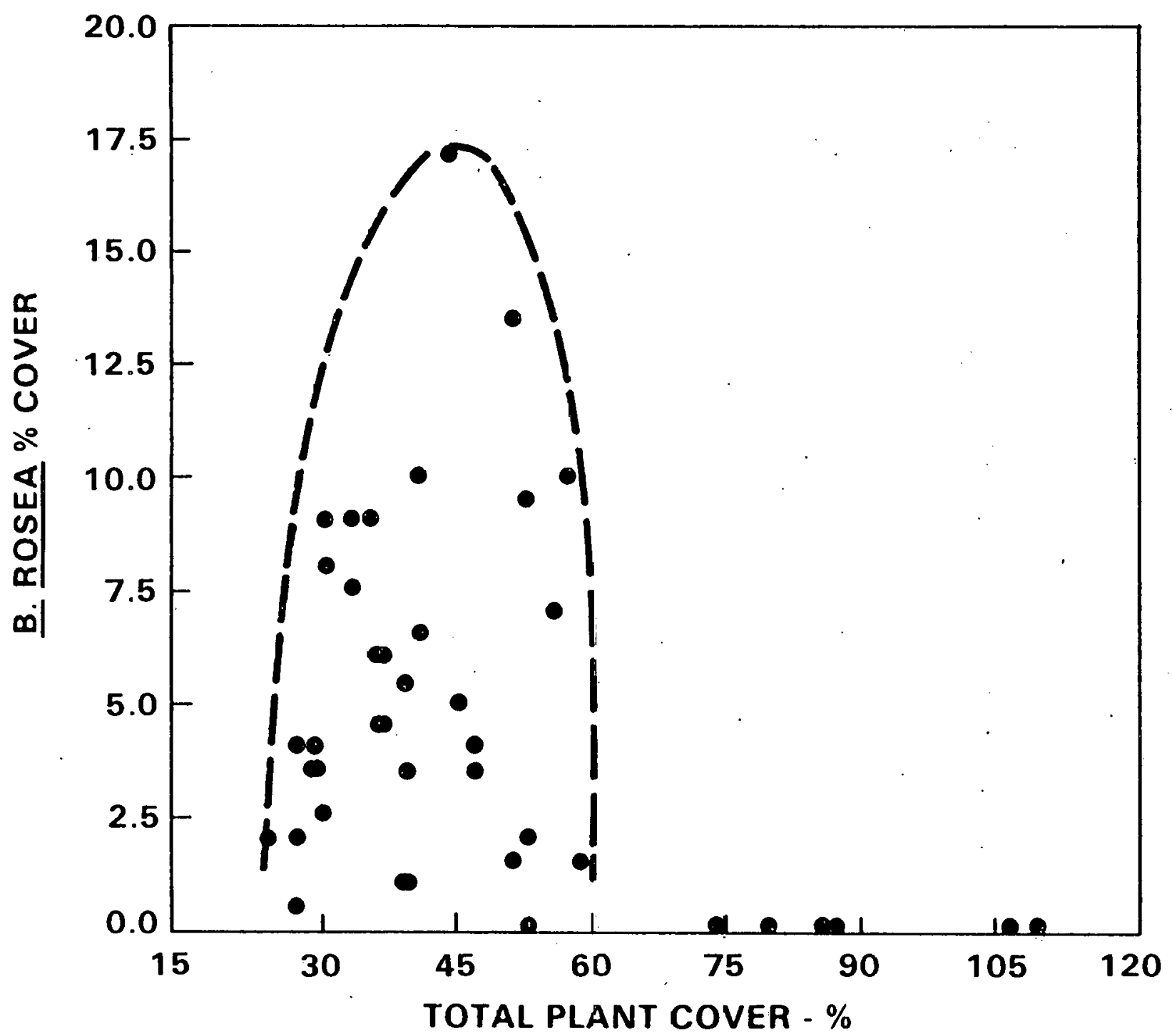

Fig. 7.--Total plant cover versus Balsamorhiza rosea cover 


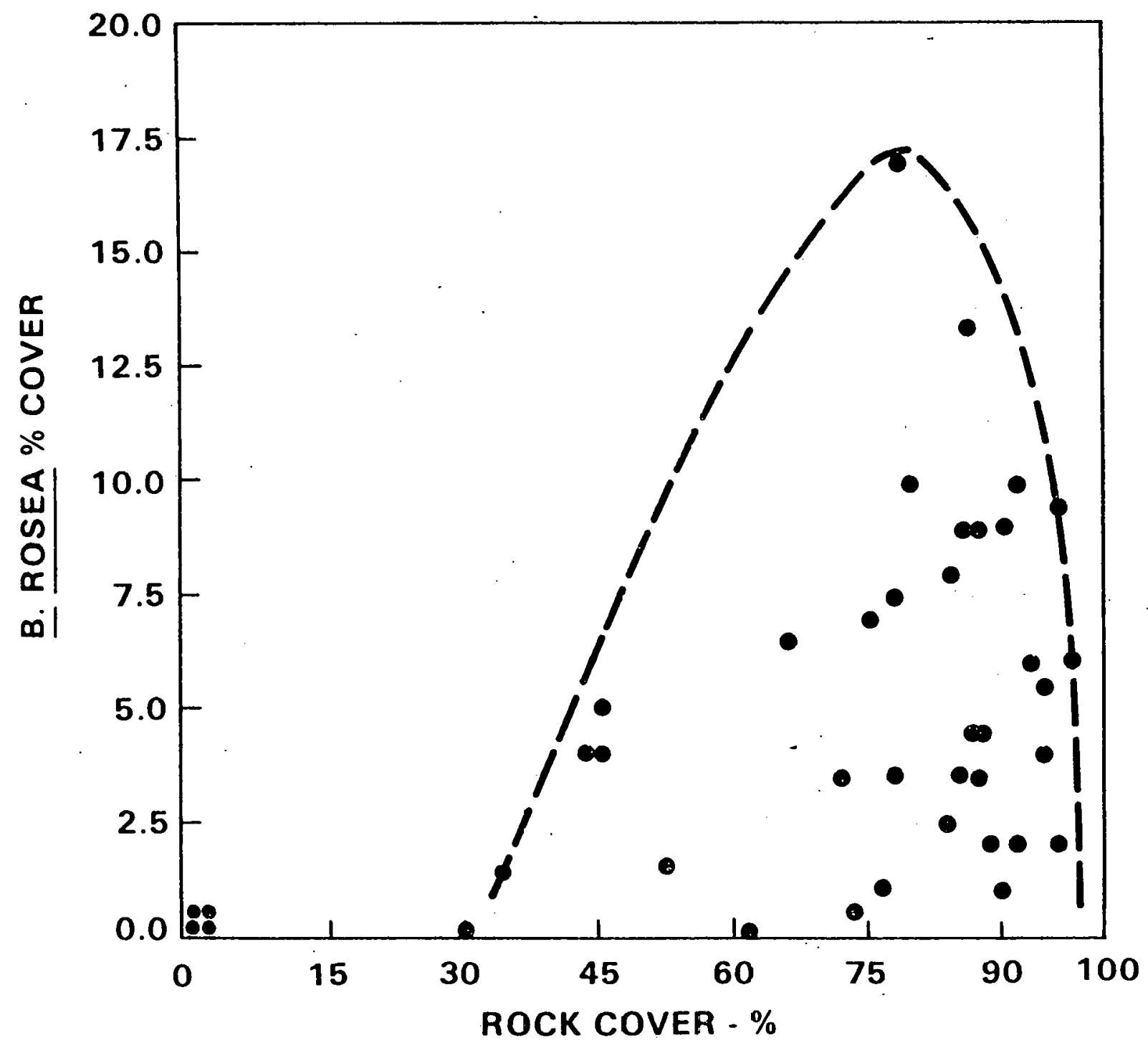

Fig. 8.--Rock cover versus Balsamorhiza rosea cover 


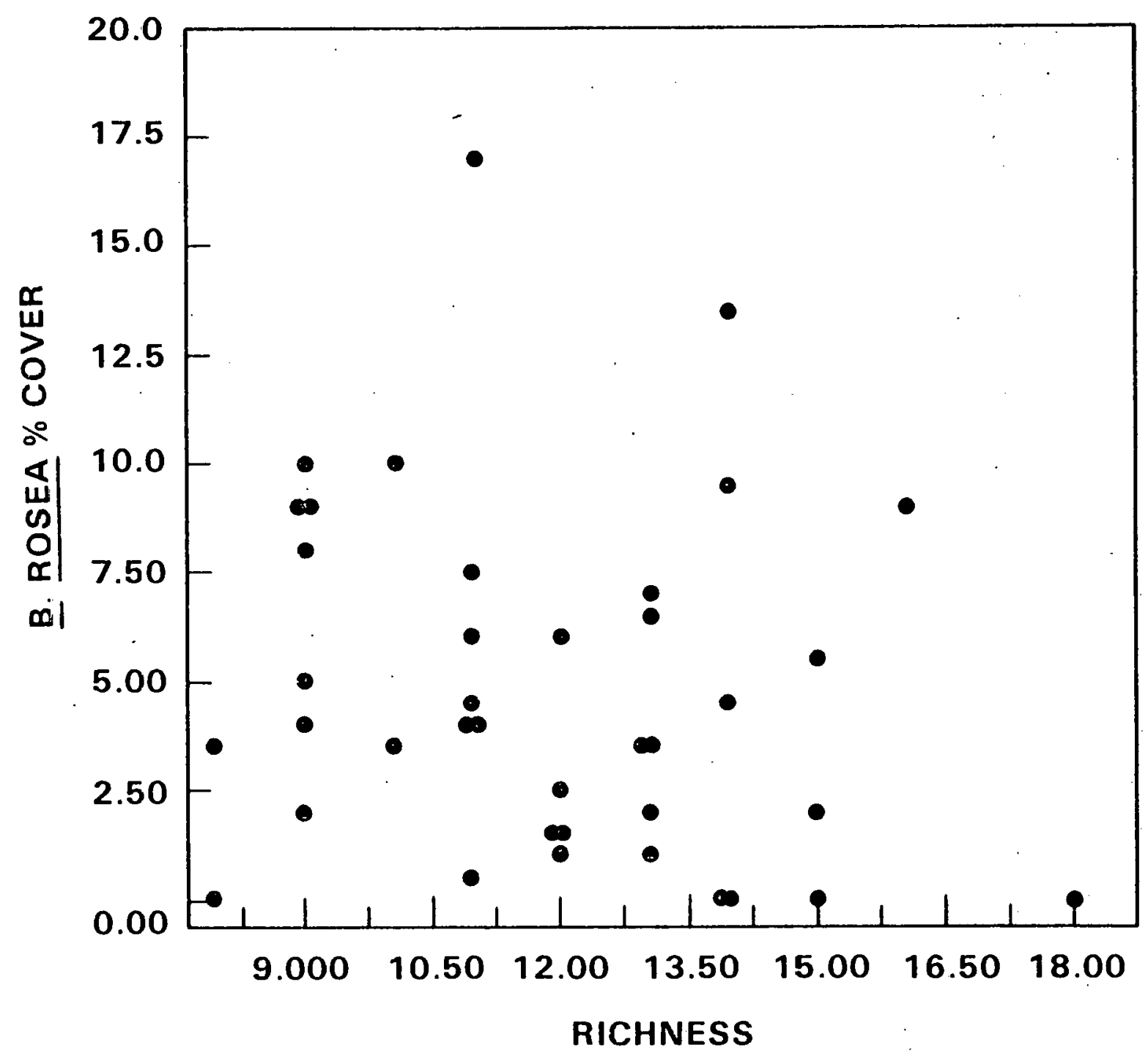

Fig. 9.--Richness index of species diversity versus Balsamorhiza rosea cover 


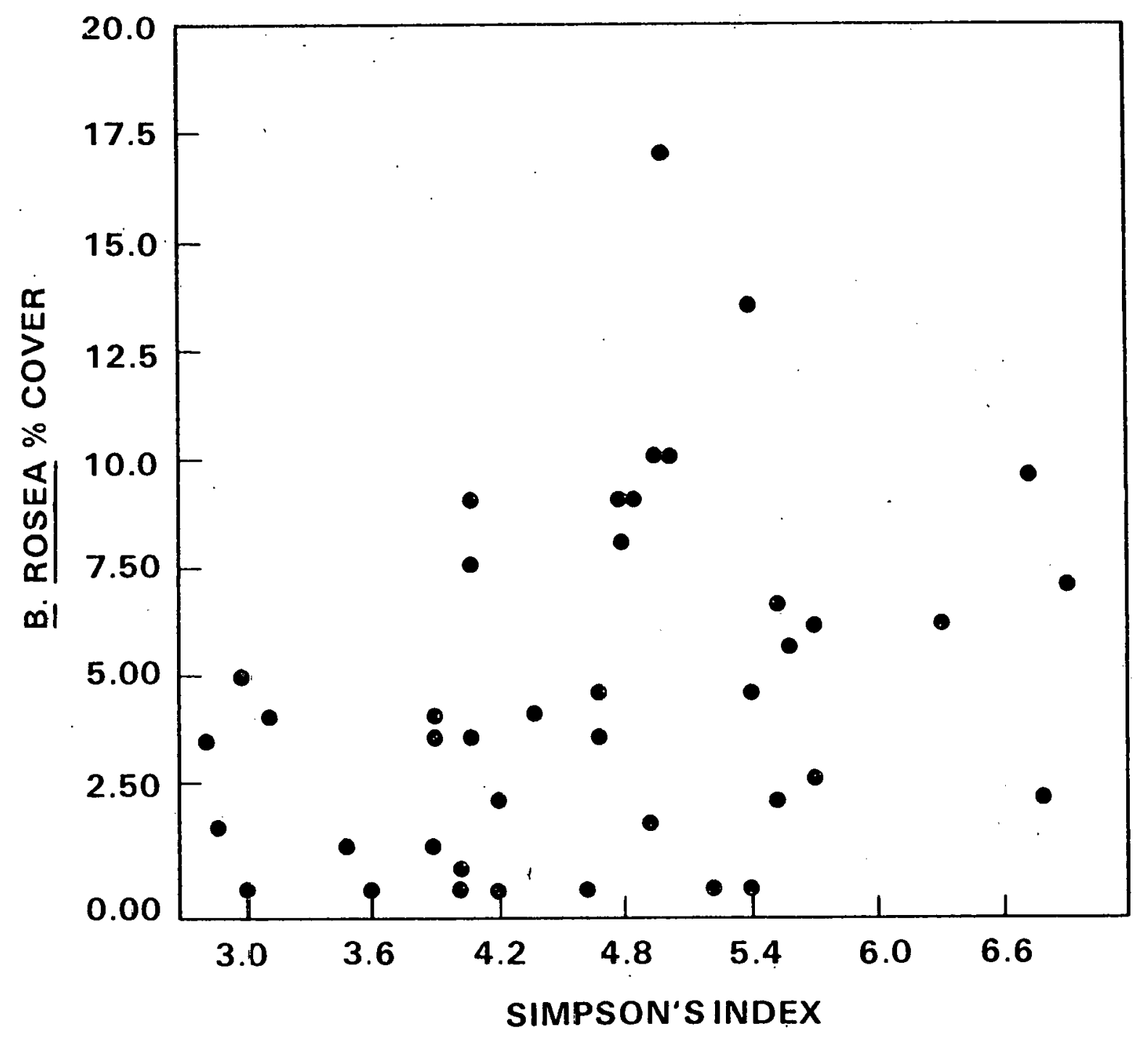

Fig. 10.--Simpson's index of diversity versus Balsamorhiza rosea cover 
The canopy cover of Agropyron spicatum versus B. rosea is depicted in $^{32}$ Figure 5. B. rosea does not appear to grow in much abundance in communities where much A. $_{\text {spicatum }}$ is present. In fact, the graph shows a rather abrupt end at about $12.5 \%$ A. spicatum below which B. rosea is present and above which it is absent.

Poa sandbergii is a much smaller plant than A. spicatum and its distribution on Rattlesnake Hills ridges is very wide. Its shared habitat with. B. rosea is evidenced in Figure 6 . However, like A. spicatum, as $P$. sandbergi increases in density, $B$. rosea decreases.

Total species cover, rock cover, and three measures of species diversity were analyzed and the results, broken down into the three categories, are represented in Table 5. B. rosea cover is included in the calculations of total cover and species diverșity.

TABLE 5.--Comparison of three plant categories

\begin{tabular}{|c|c|c|c|}
\hline Factor & No B. $\frac{\text { rosea }}{\text { Cover }}$ & $\begin{array}{l}\text { B. } \frac{\text { rosea }}{\text { Cover }} \\
>0-5 \%\end{array}$ & $\begin{array}{c}\frac{B .}{\text { Cover }} \frac{\text { rosea }}{>5 \%} \\
\end{array}$ \\
\hline Total Plant Cover & 84.7 & 39.1 & 41.7 \\
\hline Rock Cover & 10.5 & 72.8 & 83.0 \\
\hline Richness & 12.7 & 11.6 & 11.6 \\
\hline $\begin{array}{l}\text { Shannon-Weaver Index } \\
\text { (Mod.) }\end{array}$ & 5.1 & 5.5 & 6.2 \\
\hline Simpson's Index (Mod.) & 3.8 & 4.3 & 4.9 \\
\hline
\end{tabular}

Total plant cover was plotted against B. rosea cover in Figure 7: This graph uses total cover to define B. rosea's limits. Results of sampling show rather distinct boundaries within which B. rosea grows. (Balsamorhiza rosea's 
cover is included in total cover, and it is possible for canopy coverage measurements to exceed $100 \%$ if cover canopies overlap.) The results show that B. rosea is generally found in areas where total plant cover is less than $60 \%$. Rock cover, plotted in Figure 8 against $\underline{B}$. rosea cover, shows rather defined trends. B. rosea was found most heavily concentrated within a rock cover range from $65 \%$ to near $100 \%$.

Richness and Simpson's diversity indices are graphed in Figues 9 and 10 as measures of the differences in species numbers and composition versus B. rosea cover.

The plot of $\underline{B}$. rosea frequency versus $\underline{B}$. rosea cover is illustrated in Figure 11 and shows a reasonably close relationship between the two methods of estimating abundance. The one transect with exceptionally high cover for its frequency is a notable exception.

Linear correlations of these varibles with $\underline{B}$. rosea were calculated by computer program BMDP- $6 D$ and are shown in Table 6 . The first data set are based on all 41 transects. The second set includes only the 35 transects where B. rosea was present. The results of testing the correlation coefficients for significance suggest that total plant cover, rock cover, Agropyron spicatum cover, and poa sandbergii cover are linearly related to the abundance of B. rosea.

Three experiments comprise the germination studies. in the first study where seeds were planted on Rattlesnake Hills and at the foothills, the sites were observed in May, April, and June of 1979 for signs of B. rosea or B. careyana seedlings. None were found. In May of 1980 the sites were revisited. Seedlings from both the May 1979 and November 1979 plantings were counted. The results follow in Table 7 . 


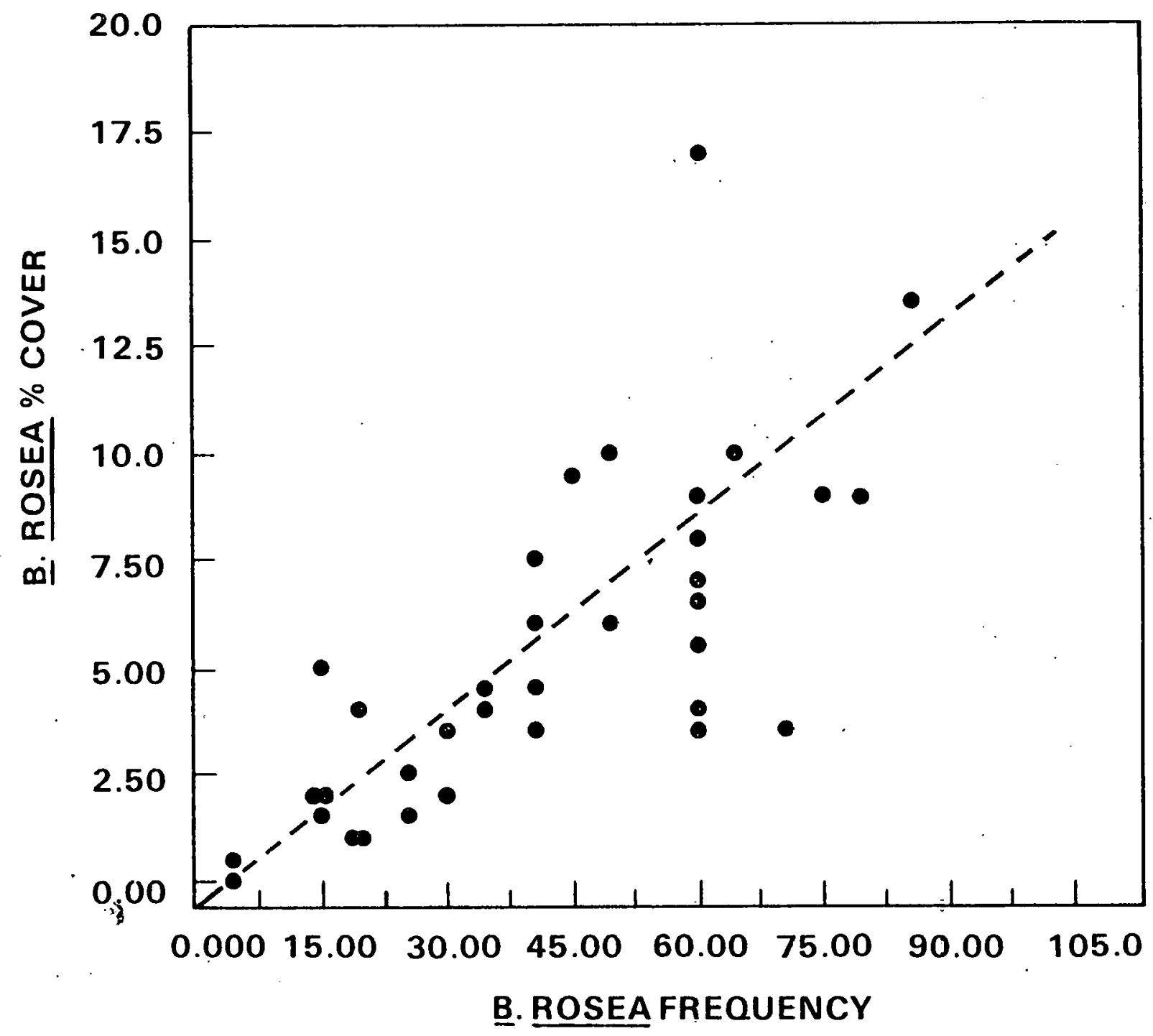

Fig. 11.--Balsamorhiza rosea frequency versus B. rosea cover 
TABLE 6.--Linear correlation coefficients of biotic factors and rock cover with abundance of Balsamorhiza rosea

\begin{tabular}{|c|c|c|c|c|}
\hline \multirow[b]{3}{*}{ Factor } & \multicolumn{4}{|c|}{ Correlation Coefficients } \\
\hline & \multicolumn{2}{|c|}{ All 41 Transects } & \multicolumn{2}{|c|}{$\begin{array}{l}\text { B. } \frac{\text { rosea transects }}{\text { on } 1 y 35 \text { samples }} \\
\end{array}$} \\
\hline & $\%$ Cover & Frequency & $\%$ Cover & Frequency \\
\hline \multicolumn{5}{|l|}{ B. rosea versus: } \\
\hline Total plant cover & $-.352^{a}$ & $-.501^{c}$ & .023 & -.114 \\
\hline Rock cover & $.522^{C}$ & $.658^{c}$ & .304 & $.434^{a}$ \\
\hline Agropyron spicatum & $-.442^{b}$ & $-.499^{C}$ & -.295 & -.229 \\
\hline Poa Sandbergii & $-.481^{b}$ & $-.577^{C}$ & -.331 & $-.417^{\mathrm{a}}$ \\
\hline Richness & -.180 & -.131 & -.112 & -.015 \\
\hline Simpson's index & $.326^{\mathrm{a}}$ & .300 & .274 & .232 \\
\hline${ }^{\mathrm{a}}$ Significance at the & $5 \%$ level & . & & \\
\hline${ }^{b}$ Significance at the & $1 \%$ level & & & \\
\hline${ }^{{ }^{c}}$ Significance at the & $0.1 \%$ le & & & \\
\hline
\end{tabular}

Laboratory germination studies of $B$. rosea and $B$. careyana continued with constant incubation for two months. No germination was noted for either species at any temperature. The seeds that had not been treated with chlorox molded after one week.

Results of seed viability as determined by a test for respiration in the embryos are listed in Table 8. The B. rosea mixed seeds were a combination of ray and disk flowers from the summer 1979 seed harvest. Only filled seeds were used which excluded some immature disk flower seeds. Viability of the B. rosea

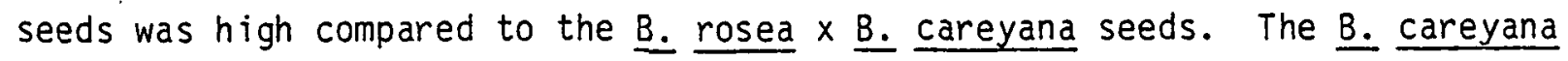
seeds tested about the same in percentage viability as the $\underline{B}$. rosea seeds. 
TABLE 7.--Seedlings from artificial planting

\begin{tabular}{|c|c|c|}
\hline Species & $\begin{array}{l}\text { Rocky so il site } \\
\text { seedlings/seeds }\end{array}$ & $\begin{array}{l}\text { Sandy Soil site } \\
\text { seedlings/seeds }\end{array}$ \\
\hline \multicolumn{3}{|l|}{ Rattlesnake Hills - $2700 \mathrm{ft}$} \\
\hline B. rosea & $8 / 60$ & $4 / 60$ \\
\hline B. careyana & $8 / 50$ & $5 / 50$ \\
\hline & . & \\
\hline Rat.tlesnạke Hills $=1200 \mathrm{ft}$ & .. $\quad \cdots$ & \\
\hline B. rosea & $15 / 60$ & $9 / 60$ \\
\hline B. careyana & $2 / 50$ & $9 / 50$ \\
\hline
\end{tabular}

TABLE 8. --Seed viability

\begin{tabular}{lcccc}
\hline \multicolumn{1}{c}{ Sample } & Total Seeds & $\begin{array}{c}\text { Respirating } \\
\text { Embryo }\end{array}$ & $\begin{array}{c}\text { Immature } \\
\text { Embryo }\end{array}$ & \% Viability \\
\hline B. rosea-mixed & 10 & 4 & 3 & 40 \\
B. rosea-ray & 20 & 8 & 8 & 40 \\
B. rosea-disk & 13 & 10 & 0 & 77 \\
B. careyana & 29 & 13 & 6 & 45 \\
B. rosea $\times$ B. careyana & 22 & 4 & 7 & 18 \\
\hline
\end{tabular}




\section{CHAPTER 4}

\section{DISCUSSION}

The hypothesis guiding this study was that $B$. rosea's distribution is significantly correlated with the measured environmental parameters. This assumes several statements are true. First, it assumes the population of B. rosea has expanded to fill its entire suitable habitat. Secondly, it assumes that the most abundant $B$. rosea growth is related to optimum environmental conditions. Third, it assumes that conditions influencing B. rosea most strongly are included in the list of parameters. And the fourth assumption is that the distribution patterns as discerned from the sampling strategy are representative of the entire study area.

Consideration of the first assumption is made with respect to the following observations: B. rosea frequently grows in clusters. In some locations it occupies only a fraction of an area which otherwise appears to be relatively homogeneous. In other locations it may appear to be nearly uniformly spread over a large area. From these observations $I$ suspect that $\underline{B}$. rosea has not filled its potential habitat. This lack of a clear pattern makes conclusions about the second assumption regarding abundance versus optimum conditions difficult.

The third statement assumes that all major parameters influencing B. rosea were considered in this analysis. The parameters investigated were chosen because their influence was expected to be significant for optimal B. rosea growth. Many other potentially important parameters were not 
considered. Some of the parameters studied may, alone or in combination with other parameters, inherently include unidentified factors. For example, the physical parameters factors in microclimate. Rock cover and soil depth are related specifically to soil temperature. Some biological factors such as seed dispersal, length of the growing season, or germination, requirements may also limit its habitat.

The fourth assumption states that the sampling was adequate to extrapolate B. rosea's distribution over the enire study area of Rattlesnake Hills. This clearly was not the case. There was no intention of using a random sampling method within its entire habitat to plot or estimate its distribution. Its spotty and sparse representation over the hillside would have yielded many more sampling misses than hits and would have required an enormous amount of sampling effort. However, sampling proceeded with expectations that the species composition in B. rosea communities would be representative.

Expectations such as simple correlations and population distribution were abandoned in favor of a trend-oriented approach to ecologically based interpretations. Some of the factors showed statistical significance based on the data and may be biologically related because they influence the microclimate.

In Figure 1 portraying the relationship between elevation and $\mathrm{B}$. rosea, the upper boundary in the data is represented by the dotted line. While it is possible that $\underline{B}$. rosea may be found in some obscure locations below $2100 \mathrm{ft}$ $(640 \mathrm{~m})$, I do not expect it to grow much below this range on these hills. It has however been located at Red Mountain as $10 \mathrm{w}$ as $1390 \mathrm{ft}$ (425 m) (Rickard, et al. 1976). Its upper range boundary is almost certainly artificial, based on the lack of higher nearby rocky ridges. The trend indicating greatest abundance around $3000 \mathrm{ft}(915 \mathrm{~m})$ may not accurately portray the optimum 
elevation as the sample taken at that point was unusual in several ways-specifically, it resembled a shallow gravel pile and probably was artifically disturbed by man's actions. Even without this point, however, the data appear grouped around a mean near $3000 \mathrm{ft}(915 \mathrm{~m})$.

Results of the evaluation of $B$. rosea abundance versus slope aspect varied from my expectations. I had hypothesized that $B$. rosea would be found predominantly on one type of slope; probably south slopes. This would help define its heat and light requirements. However, in almost every case $\underline{B}$. rosea could be located on low slopes of each aspect. As shown in Figure 2, there was no clear indication that one aspect was preferred over another.

B. rosea was not found on slopes with angles greater than $23.5^{\circ}$. This may be due in part to the fact that most steep slopes in the Rattlesnake Hills are northern slopes with limited insolation. B. rosea grows on flat ground, but the search for angled sample areas caused an undersampling of these areas. It is probable that the dotted line in Figure 3 approximates the actual upper boundary where abundance tends to decrease with elevation.

Analysis of $B$. rosea abundance with soil depth was the most fruitful in the study. It appears to have a distribution skewed to the left in Figure 4 requiring some soil to initate growth but being confined to shallow soils. Its linear correlation coefficients are the highest of the physical factors. However, as with most of the other factors, good linear correlations where the coefficient approaches 1 or -1 cannot be expected for populations which have not filled their potential habitat or for those factors whose curves must start near zero.

Results of the vegetation cover and frequency analysis depict differences in community structures with the presence and increased abundance of B. rosea. The $\underline{B}$. rosea communities are frequently comprised of the forb 
species Phlox hoodii, Haplopappus stenophyllus, the low shrub species Eriogonum. sphaerocephalum and Eriogonum thymoides; Crepis occidentalis, and Lomatium macrocarpus; and the grass species of Poa sandbergii, Agropyron spicatum, and Bromus tectorum.

The transects sampled in areas where B. rosea was absent are characterized by abundant growth of the grasses Agropyron spicatum, and Poa sandbergii, in greater quantities than in $\underline{B}$. rosea areas. Artemisia tridentata was frequently found on these sites. No other species were found at these sites with an average canopy covering exceeding $2 \%$.

The dramatic reduction of $\underline{B}$. rosea's abundance with Agropyron spicatum's presence is illustrated in Figure 5. This graph looks suspiciously similar to Figure 4 on soil depth. This observation is not surprising when coupled with the trend that A. spicatum's abundance increases with soil depth.

The decreased abundance of B. rosea canopy coverage with increased guantities of poa sandbergij is a much less severe trend as indicated by the dotted line in Figure 6 . It appears inversely related to $\underline{B}$. rosea's cover, and its upper limits decrease almost linearly. P. sandbergii, which has a much smaller size and root base than $\underline{A}$. spicatum, is less likely to shade $\underline{B}$. rosea or absorb as much available water or nutrients.

The abundance of $\underline{B}$. rosea as a function of total plant cover is represented by the parabolic curve in Figure 7. This shows some rather definite limits and an optimum range for $\underline{B}$. rosea. The results in Table 4 show almost identical average total canopy cover percentages for the high and low B. rosea transects. The total cover in the transects where $\underline{B}_{\text {. }}$ rosea was absent is twice the amount as the values in the B. rosea transects. A comparison of canopy heights between the sets would probably show similar results with the $\underline{B}$. rosea 
plots half as high as the no $\underline{B}$. rosea plots. These factors suggest that the competition for light, water, or minerals prevents the expansion of $\underline{B}$. rosea into areas of greater canopy coverage.

Rock cover as a determinant factor in $\underline{B}$. rosea's abundance is represented in Figure 8 by a curve skewed slightly to the right toward the rockier soils. The average rock cover in the three categories represented in Table 4 also shows this tendency. The rock cover curve is inversely related to the soil depth curve.

The results of the analysis of species diversity do not add much information as there is little difference among the three categories of $\underline{B}$. rosea abundance with the three indices. Each category had about the same average number of species per transect. Of possible interest is the observation that the high $B_{\text {. }}$ rosea cover class had a slightly higher Simpson's index value. This suggests an increased number of common species found in these plots.

Results of the data analysis up to this point suggest several possible reasons for the $l$ imited distribution of $\underline{B}$. rosea. Its presence only in open vegetation suggests that it requires full sunlight. Another possiblity is that B. rosea cannot compete for water or other requirements with other plants in less harsh environments. Comparison of the B. rosea carrot-like taproot with the many fine roots of grasses may indicate a possible explanation for B. rosea's inability to grow in grass stands from a moisture standpoint. However, its close relative $B_{\text {. }}$ careyana with a similar taproot lives easily in these habitats not occupied by $\underline{B}_{-}$rosea. The relationship illustrated in Figure 6 showing total cover versus B. rosea cover may add credibility to its intolerance of competition as $\underline{B}$. rosea was not found growing where total cover exceeded $60 \%$. However, this may simply indicate some unidentified factor in the harsh environment where total cover is seldom greater than $60 \%$ is required for B. rosea's survival. 
Other possible explanations may include a nutrient factor present in rocky soils and absent in others. Or there may be some unidentified biological factor limiting its distribution. Perhaps it requires the cold climate found only in the harshest. conditions near the top of Rattlesnake Hills. It is not found at elevations below that with an average maximum air temperature exceeding $19 \mathrm{C}$. (Thorp and Hinds, 1977). Several members of the genus are known to require cold treatment for germination and this cold treatment appears to have stringent boundaries (Young and Evans, 1979). Even after stratification, germination may be restricted to comparatively low temperatures. Yet its early season blooming cycle must require warm soil temperatures during the day during the season when moisture is available. This may explain its growth in rock environments, as the rocks warm up before sandier soil does, and may allow B. rosea access to the limited water supply for its early growth.

Laboratory attempts to break seed dormancy failed and were, therefore, unable to provide a set of conditions required for to overcome any germination inihibitions. Many of the seeds, however, appeared viable. The lack of immature seeds in the B. rosea disk group partially was the result of very careful selection as many disk flowers do not produce mature seed by the end of the ir growing season. Reduced viability in the apparent $\underline{B}$ rosea $\times \underline{B}$. careyana seeds supports the likelihood that these are hybrid seeds.

Many of these questions and suppositions lead us to the germination studies conducted in an effort to answer the required factor versus competition concern. B. rosea seeds were planted at $1200 \mathrm{ft}(365 \mathrm{~m})$ and $2700 \mathrm{ft}(823 \mathrm{~m})$ sites to see if $\underline{B}$. rosea could produce seedlings at the lower elevation with its different climate. The seeds were planted at both sites in rocky and silty grassland soil to evaluate differences in growth as influenced particularly by soil type and competition competition. B. careyana germination was tested simultaneously to aid in the interpretation of the results. 
The results of this germination study are puzzling. It is apparent that, when planted in any of these locations, some seeds can germinate. Survival to reproductive age has not yet been established and may take several years of study. However, the fact that seedlings were discovered in each plot intensifies the question of why $\underline{B}$. rosea is limited to hill crests, and is its existence feasible in the foothills of these mountains. A related question is whether its habitat is expanding, retreating, or remaining static. My only evidence suggesting any change are my observations that $\underline{B}$. rosea has invaded many rocky areas that have been scraped by road construction machinery or have otherwise been disturbed. The appearance of these sites is that the top soil has been removed leaving a rocky, shallow soil substrate. B. rosea apparently invades or reestablishes itself in those areas matching the profile that is developing from this study. 


\section{CHAPTER 5}

CONCLUSIONS

Results of the analyses evaluating relationships between Balsamorhiza rosea and various biotic and abiotic factors have led me to the following conclusions:

1. Based on the absence of $B$. rosea found below $2100 \mathrm{ft}(648 \mathrm{~m})$ in the Rattlesnake Hills and $13 \overline{90} \overline{\mathrm{ft}}(425 \mathrm{~m})$ on Red Mountain, it appears there is some. lower elevational limit for $B$. rosea's natural growth.

2. B. rosea grows naturally in shallow, rocky soils of limited total plant canopy cover.

3. B. rosea seldom grows in tall bunchgrass or in tall shrub communities.

4. B. rosea's density is inversely related to Poa sandbergii and Agropyron spicatum plant cover

5. Slope aspect by itself does not appear to be a factor in the distribution of B. rosea.

6. When artifically $\mathrm{planted,} \mathrm{B.} \mathrm{rosea} \mathrm{seeds} \mathrm{can} \mathrm{germinate} \mathrm{at} \mathrm{elevations}$ lower than, their natural occurrence and in silty, moderately grassy soils.

I suspect that the factors influencing $\underline{B}$. rosea's distribution are very much interrelated and this increases the difficulty in identifying the most important contribution. One example of this is that slope aspect does not appear to be a major factor determining B. rosea's distribution. However, certain slope aspects combined with steep slope angles probably do effect B. rosea's presence or absence.

Further investigation into Balsamorhiza rosea's distribution should concentrate on factors such as soil temperature, soil moisture, soil chemistry, light requirements, and seed dormancy. And of course, the important question, 
which can be studied by future observations, remains--whether the B. rosea seedlings can survive and reproduce in the new environment in which they have been planted. 


\section{LITERATURE CITED}

Brown, M. B., ed. 1977. BMDP-77 Biomedical Computer Programs. University of California Press, Berkeley.

Daubenmire, R. 1959. A canopy-coverage method of vegetational analysis. Northwest Science 3(1):43-64

Department of the Interior, Fish and Wildlife Service. 1975. Threatened or endangered fauna or flora. Federal Register $40(127): 27885$.

Hill, M. 0. 1973. Diversity and evenness: A unifying notation and its consequences. Ecology 54:427-432.

Hitchcock, C. L., and A. Cronquist. 1973. Flora of the Pacific Northwest. University of Washington, Seattle.

Hitchcock, C. L., A. Cronquist, M. Ownbey, and J. W. Thompson. 1955-1969. Vascular plants of the Pacific Northwest. 5 Vols. University of Washington Press, Seattle.

Machlis, L., and J. G. Torrey. Plants in action--A laboratory manual of plant physiology. 1956. W. H. Freeman and Company, San Francisco.

Ownbey, M., and W. A. Weber. 1943. Natural hybridization in the genus Bàlsamorhiza. Am. J. Bot. 30(3):179-187.

Rickard, W. H. , B. Kleeper, R. H. Sauer, and J. M. Thorp. 1978. Balsamorhiza rosea and Eriogonum thymoides in Benton County, Washington. Northwest Science 52(2):110-118.

Sauer, R. H., and S. L. Owzarski. 1979. Collection and analyses of vegetative cover data. Battelle Pacific Northwest Laboratories, Richland, WA.

St. John, H. 1956. Flora of Southeastern Washington and adjacent Idaho. State College of Washington Press, Pullman, WA.

Thorp, J. M., and W. T. Hinds. 1977. Microclimates of the Arid Lands Ecology Reserve 1968-1975. Battelle Pacific Northwest Laboratories, Richland, WA.

Weber, W. A. 1946. A toxonomic and cytological study of the genus Wyethia, family Compositae with notes on the related genus Balsamorhiza. Am. Midl. Nat. 35:400-452.

Young, J. A., and R. A. Evans. 1979. Arrowleaf balsamroot and mules ear seed germination. $J$. of Range Management $32(1): 71-74$. 